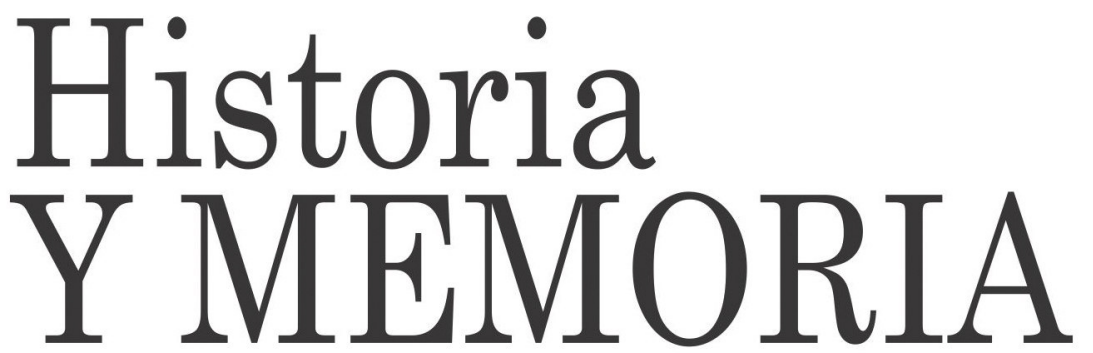

Interdiscursividad en la serie de cuadros de castas atribuida al pintor novohispano José Joaquín Magón

Luis Augusto Mora Bautista Abel Fernando Martinez Martín Páginas: 245 - 295 


\title{
Interdiscursividad en la serie de cuadros de castas atribuida al pintor novohispano José Joaquín Magón.
}

\author{
Luis Augusto Mora Bautista ${ }^{1}$ \\ Abel Fernando Martínez Martín ${ }^{2}$ \\ Universidad Pedagógica y Tecnológica de Colombia
}

Recepción: 16/08/2013

Evaluación: 29/10/2013

Aceptación: 24/03/2213

Artículo de Investigación e Innovación.

\section{Resumen}

Este artículo analiza una serie de cuadros de castas atribuida a José Joaquín Magón, con el objeto de establecer su peculiaridad: el estar acompañada de un texto a manera de leyenda literaria que emite juicios de valor sobre las condiciones morales y sociales de los "productos". Se establece su relación con las características básicas de este género pictórico, para luego compararla con la serie encargada por el arzobispo Lorenzana a Magón y llevada a España. Se considera luego la condición problemática de la relación entre leyenda, cartela y obra en esta serie, para por último, basados en el análisis de la interdiscursividad,

\footnotetext{
${ }^{1}$ Filósofo, Universidad Nacional de Colombia. Estudiante del Doctorado de Historia, Universidad Pedagógica y Tecnológica de Colombia. Profesor Ocasional Tiempo Completo, Escuela de Filosofía, Universidad Pedagógica y Tecnológica de Colombia. luisaugusto.mora@uptc.edu.co

${ }^{2}$ Candidato a Doctor en Historia, Universidad Pedagógica y Tecnológica de Colombia. Profesor Asociado, Escuela de Medicina, Universidad Pedagógica y Tecnológica de Colombia. abelfmartinez@gmail.com.
} 
reconocer la taxonomía y jerarquización socio-racial que están representadas en esta serie de cuadros de mestizaje.

Palabras Clave: Cuadros de castas, interdiscursividad, José Joaquín Magón, Reformas Borbónicas, Nueva España.

\title{
Interdiscursivity in the series of casta paintings attributed to the New Spanish painter José Joaquín Magón
}

\begin{abstract}
This article seeks to analyze a series of casta paintings attributed to José Joaquín Magón. Furthermore, the characteristic of including a literary legend that makes value judgments about the moral and social conditions of the "products" will enable the establishment of peculiarities. This study traces the relationships between the casta paintings and the basic features of this pictorial genre, comparing them with a series that Magón was ordered to paint and which was taken to Spain by the archbishop Lorenzana. Finally, we examine the problematic condition of the relationship between legend, box, and work in this series, and eventually, based on the analysis of interdiscursivity, we consider taxonomy and the socio-racial classification represented in this series of miscegenation paintings.
\end{abstract}

Key words: Casta paintings, interdiscursivity, José Joaquín Magón, bourbonic reforms, New Spain. 


\section{Interdiscursivité dans la série de tableaux de castes attribuée au peintre néohispanique José Joaquín Magón}

\section{Résumé}

Cet article analyse une série de tableaux de races attribuée à José Joaquín Magón, afin de préciser sa particularité: le fait d'être accompagnée d'un texte en guise de légende littéraire qui exprime des jugements de valeur sur les conditions morales et sociales des "produits". Nous établissons un lien avec les traits fondamentaux de ce genre pictural, et ensuite nous comparons les peintures de Magón avec la série commandée par l'archevêque Lorenzana à Magón et emportée en Espagne. Nous étudierons ensuite le problème de la relation entre la légende, le cartouche et l'œuvre dans cette série. Finalement, sur la base de l'analyse de l'interdiscursivité, nous chercherons à reconnaître la taxonomie et la hiérarchisation socio-raciale qui ont été représentées dans cette série de tableaux de métissage.

Mots clés: Tableaux de races, interdiscursivité, José Joaquín Magón, Réformes bourboniennes, Nouvelle Espagne.

\section{Introducción}

En fecha indeterminada, probablemente más allá del año $1770^{3}$, el pintor poblano José Joaquín Magón, realizó una de las series más peculiares de toda la llamada Pintura

\footnotetext{
${ }^{3}$ La serie, que pertenece a una colección privada en México, es atribuida por María Concepción García Sáiz al pintor novohispano José Joaquín Magón, por sus similitudes con otra serie de 16 cuadros de castas de Magón, pintada en 1770 para el arzobispo de México, Francisco Antonio Lorenzana y Butrón, entre 1766 y 1772. Esta serie fue trasladada a España cuando Lorenzana fue nombrado arzobispo de Toledo (1772) y actualmente se encuentra en el Museo Nacional de Antropología de Madrid.
} 
de Castas o Cuadros de Mestizaje. ${ }^{4}$ Esa peculiaridad es debida a un texto, a modo de leyenda literaria, en el que se emiten juicios de valor sobre las condiciones morales y sociales de los híbridos ${ }^{5}$ que aparecen representados en la pintura. Tradicionalmente, las series de castas están acompañadas de una cartela con textos que identifican $\mathrm{y}$, a veces, numeran las categorías raciales producto de la mezcla de españoles, indios y negros, con sus diversas combinaciones (Imágenes 1 y 2). ${ }^{6}$

${ }^{4}$ Pintura de Castas o Cuadros de Mestizaje son categorizaciones empleadas
indistintamente por los especialistas. En la Nueva España, en el siglo XVIII
se hacen notorias las series de cuadros de mestizaje, conocidos también
como cuadros de castas, de los que se han identificado hasta hoy más de
100 series, compuestas, por lo general de 16 cuadros, en un único formato,
cuyo tema son las combinaciones étnicas. Género secular novohispano,
de diversa calidad, formatos y técnicas, primordialmente óleo sobre tela,
madera y cobre, frecuentemente incompletas y sin datar, pintadas por
reconocidos maestros (Arellano, Rodríguez Juárez, Ibarra, Bustos, Islas,
Cabrera, Berruecos, Morlete, Alcibar, Basarás, Torres, Guiol) y por autores
anónimos durante más de una centuria (finales del siglo XVII a principios
del XIX); desaparecen a principios del siglo XIX. La mayor parte de estos
cuadros se han encontrado por fuera de México y se caracterizan por su
alto grado de semejanza en las escenas pintadas. Son de mayor tamaño las
series realizadas por los artistas con mayor trayectoria, así como el formato
pequeño es predomínate entre los anónimos. ${ }^{5}$ Pedro Alonso O' Crouley, en su Idea compendiosa del Reyno de Nueva España (1774), afirma: "las calidades y linajes de que estas castas se originan; son español, indio y negro, sabido es que de estas dos últimas ninguna disputa al español la dignidad y estimación, ni alguna de las demás quiere ceder a la del negro, que es la más abatida y despreciada (...) Si el compuesto es nacido de español e indio sale mestizo, de éste y español castizo, y de éste y español sale ya español (...) de español y negro nace el mulato, de éste y español morisco, de éste y español tornatrás, de éste y español tente en el aire, que es lo mismo que mulato, y por esto se dice y con razón que el mulato no sale del mixto, y antes bien como se pierde la porción de español y se liquida en carácter de negro (...) Por lo que respecta a la confección de negro e indio sucede lo mismo, porque se gradúa de este modo: de negro e indio, lobo; de éste e indio chino, de éste e indio albarazado, que todos tiran a mulato". En: Illona Katzew, La pintura de castas. Representaciones raciales en México del siglo XVIII, (Madrid/México D.F.: 2004), 192.

${ }^{6}$ Las imágenes reproducidas en este texto proceden del libro de García Saiz, María Concepción (1989). Las castas mexicanas. Un género pictórico Americano. Olivetti, Milán, que incluye las dos series de Magón y del libro de Illona Katzew, La pintura de castas...Turner, que no cita la serie atribuida a Magón. 
Ahora bien: ¿por qué en más de 100 series de castas identificadas por los especialistas en estos temas, sólo se da esta peculiaridad en la serie atribuida a Magón? María Concepción García Sáiz, investigadora española, en su obra: Las castas mexicanas (1989), advierte que no hay coincidencia entre la leyenda que prejuzga el carácter y la catadura moral de estos individuos y lo que está representado en el cuadro:

Una revisión detallada de textos y representaciones plásticas indica con claridad que el artista no se ciñó a tales pautas, dejando en blanco el espacio destinado a contenerlas que, probablemente, fue rellenado por otra persona o tal vez por él mismo, pero siguiendo indicaciones ajenas, ya que es arduo buscar una relación entre ambas sobretodo en los casos más evidentemente peyorativos. Es difícil imaginarse al lobo (Imagen 3) como de "mala ralea, Herodes de bolsas y faltriqueras", cuando se nos representa como un pequeño que reprocha a su padre, negro, que esté dormitando sin hacer nada mientras su madre se afana en las tareas caseras, o al tente en el aire (imagen 4), que ayuda a sus padres a confeccionar un adorno floral, como "ingerto malo". ${ }^{7}$

La tesis de García Sáiz es que al parecer se trata de otra persona o el mismo autor posteriormente, pero con directrices ajenas, quien añade, después de haber sido pintados los cuadros por Magón, el carácter y la moral de estos individuos en una leyenda aclaratoria, que a veces aparece dentro de una cartela con marco rococó; texto que no parece coincidir con lo que está representado en la pintura, como se ve en los cuadros X, XVI, XIV y XV de la serie (Imágenes 3,4,5 y 6). La descripción del carácter

${ }^{7}$ María Concepción García Saiz, Las castas mexicanas. Un género pictórico Americano. (Milán: Olivetti, 1989), 102. 
moral del producto, que aparece en la leyenda, siempre es problemática por referirse a un niño que, como es obvio, no evidencia una condición adulta definida; al respecto, es necesario anotar que el lobo de "mala ralea y Herodes de bolsas y faltriqueras", niño del cuadro X (Imagen 3), aparece como un adulto progenitor en el cuadro XI (Imagen 7), donde se representa con un cuchillo en su mano derecha y una bolsa en la izquierda.

La relación problemática entre cartela, leyenda y cuadro es mucho más compleja de lo insinuado por García Sáiz. Toda la serie adquirida por el arzobispo Lorenzana tiene las cartelas rococó. En la serie atribuida a Magón, el texto añadido, muchas veces se sale del límite espacial reservado por el pintor en la cartela. En algunos cuadros de esta serie la cartela aparece difuminada (IX y XIII) (Imágenes 8 y 9) o aparece totalmente borrada (V) (Imagen 10), o no aparece (XI, XIV y XV) (Imágenes 7, 5 y 6), y la leyenda es puesta sobre columnas o sobre una especie de piel animal, como se aprecia en el cuadro X (Imagen 3). Comparando las cartelas de las dos series encontramos que las denominaciones de las castas tienen diferentes ortografías $^{8}$ y que la serie llevada a España por el arzobispo Lorenzana no describe las cualidades morales de las castas representadas y utiliza números arábigos; mientras la serie atribuida a Magón utiliza números romanos para identificar y describir las cualidades morales de sus 16 cuadros. En la serie de Lorenzana se escribe Calpamulato (8), Coyote (14 y 15), Lobo (10), Givaro (9), Sambahiga (12) y Tente en el Aire (16), mientras en la segunda serie, la atribuida a Magón, aparece escrito de manera diferente

${ }^{8}$ La Real Academia Española de la Lengua, fue fundada en 1713 por iniciativa de Juan Manuel Fernández Pacheco, marqués de Villena y duque de Escalona, con el propósito de fijar las voces y vocablos de la lengua castellana en su mayor propiedad, elegancia y pureza. Sólo a partir de su creación se empezaron a unificar criterios de pronunciación, escritura, ortografía y demás aspectos del lenguaje. 
Calpa Mulato (VIII) Collote (XIV y XV), Lovo (X), Gibaro (IX), Sambayga (XII) y Tenteenelayre (XVI).

Profundizando en la tesis de García Saiz, pueden existir tres posibles explicaciones. La primera, que Magón hubiese dejado las cartelas sin texto, el cual fue añadido con posterioridad. La segunda, que Magón hubiese incluido en la cartela sólo un texto tradicional, tal y como lo hizo en la serie encargada por el arzobispo Lorenzana y que posteriormente este texto fuese borrado y en su lugar se introdujese la leyenda actual. Y en tercer lugar, que el mismo Magón a petición del cliente, quien le hubiese facilitado la leyenda, la hubiese incluido.

Siendo series realizadas siempre por encargo, no ha sido tomado suficientemente en cuenta el papel primordial que juega el cliente en la pintura de castas. Esto es, el cliente encarga a un maestro reconocido una serie para satisfacción estética, artística o como souvenir, para exhibir en su país de origen. En este sentido, I. Katzew señala que entre los clientes era frecuente encontrar altos funcionarios del virreinato y altas jerarquías de la Iglesia novohispana, generalmente afectos a las reformas borbónicas, como el arzobispo Lorenzana, quien expulsó a los jesuitas por orden de Carlos III e impulsó reformas urbanísticas en la ciudad de México:

En el inventario que se hizo en 1779 a la muerte del Virrey Antonio María Bucareli (1771-1779) se describen seis pinturas de castas valoradas en setenta y dos pesos, suma considerable que da indicios de la calidad de las obras (a pesar de que no se menciona el nombre del artista). Se sabe también que Bucareli envió un conjunto de cuadros de castas con el famoso científico y burócrata español Antonio de Ulloa (1716-1795), quien visitó México en 1777, a su sobrina [...] a Sevilla. ${ }^{9}$

$\overline{9}$ Illona Katzew, La pintura de castas... 147. 
Otra función de estas series de pinturas, más allá del ideario artístico y estético, que enlaza con el espíritu ilustrado y reformista borbónico de la segunda mitad del siglo XVIII, es la de informar y documentar la realidad americana. Es destacable la serie procedente del Virreinato del Perú, compuesta por veinte lienzos encargada por el Virrey Amat y Junyent y remitida al entonces príncipe de Asturias en 1770, con el fin de contribuir a la formación del Gabinete de Historia Natural. ${ }^{10}$ Con respecto a esta serie, Anne Ebert afirma que al contrario de "gran parte de las series mexicanas, la serie peruana representa a las personas más bien a modo de retrato y no las ubica en una escena de la vida cotidiana". ${ }^{11}$ En su remisión del Virrey del Perú señala que estos cuadros describen las "raras producciones que ofrecen estos dominios, la notable mutación, de aspecto, figura y color, que resulta en las sucesivas generaciones de la mezcla de Indios y Negros, a que suelen acompañar proporcionalmente las inclinaciones y propiedades". ${ }^{12}$

El costo de estas pinturas era múltiple y variaba, tanto por la calidad del artista contratado, como por el tipo de cliente, ya que no es lo mismo un cliente que las

\footnotetext{
${ }^{10}$ El proyecto de formación en España de un Gabinete de Historia Natural fue obra del marino ilustrado Antonio de Ulloa, quien expuso su idea en 1752 al rey Fernando VI, señalándole la necesidad de fomentar los estudios de mineralogía, botánica y zoología, pero no fue posible la creación del Real Gabinete hasta el reinado de Carlos III, quien en 1771 adquiere un abundante material de los tres reinos, animal, vegetal y mineral, además de libros y objetos de arte, perteneciente al comerciante y coleccionista de Guayaquil, Pedro Franco Dávila, que sirve de base para fundar el gabinete, que es abierto al público en 1776. Véase Arinero Calatayud, María Ángeles "El Real Gabinete de Historia Natural de Madrid", En: M. Sellés, J.L. Peset\& A. Lafuente (comp.), Carlos III y la ciencia de la Ilustración, (Madrid: Alianza Editorial, 1987); 263-76.

${ }^{11}$ Anne Ebert, "La representación de las américas coloniales en los cuadros de castas", Revista Scientia Vol. X: No. 10: 139-152.

${ }^{12}$ Virrey Amat y Junyent, Lima 13 de mayo de 1770, cifra, en: Anne Ebert, "La representación de las américas...
} 
desea para colocarlas en su casa, o aquel que las lleva como recuerdo de su paso por América, o el rey que las incluirá en un gabinete de Historia Natural a modo de producciones maravillosas, que ofrece la diversidad de sus dominios coloniales americanos. Las pinturas estaban destinadas a las elites españolas, de las que no excluimos a los españoles americanos (criollos), ya que por su costo no eran accesibles a otras personas. ${ }^{13}$ Además, y esto es lo más importante, el cliente quería ver expuesta y representada la sociedad racial novohispana, de la que él, como blanco y como español, estaba ubicado en la cumbre de la pirámide social colonial. El español es el número 1 de todas las series ${ }^{14}$ y el que más aparece representado en los cuadros de castas, dado que él, como blanco, determina las posibilidades combinatorias al ser el referente necesario del proceso de blanqueamiento. ${ }^{15}$ En la serie atribuida, las leyendas recalcan ese carácter de superioridad y la ubicación en la cima de la pirámide social del españolblanco. El resto de las castas y sus combinaciones están estigmatizados social y moralmente, siendo el blanco español, tanto americano como europeo, el que discrimina

\footnotetext{
${ }^{13}$ En inventarios y testamentos se aprecia la variación en los precios de los cuadros de castas, que van desde dos reales (un cuarto de peso) hasta 12 pesos, cada uno de los 16 cuadros, en el inventario de un Virrey novohispano.

${ }^{14}$ El primer cuadro de todas las series lo ocupa la mezcla de español con india que produce mestizo (a).

${ }^{15}$ En Europa se tenía la noción equivocada de que en el Nuevo Mundo todos eran mestizos y, racialmente inferiores, escribe el misionero y cronista jesuita Joseph Gumilla, quien destaca la posibilidad de mejorar la sangre, tanto para la mezcla de españoles con los indios como para la mezcla de españoles con los negros, a diferencia de la Nueva España, donde tal posibilidad de blanqueamiento estaba reservada sólo a los indios (Cifr., Illona Katzew, La pintura de castas...49). Sin embargo, legislaciones de 1794 y 1795 actuaron en sentido contrario. Una real cédula declaró que los expósitos podían acceder a privilegios reservados a los hijos legítimos y otra estableció los aranceles para "las gracias al sacar", sistema de ascenso social, mediante el cual mulatos y pardos podían comprar la blancura legal y así convertirse en personas honorables.
} 
y estigmatiza al otro por su falta de calidad $^{16}$ y por su falta de limpieza de sangre, por su sangre mezclada. ${ }^{17}$ La subordinación social se representa como inferioridad racial, moral y psicológica que legitima la dominación ejercida por la minoritaria élite de españoles europeos y americanos en el sistema colonial novohispano. Consigna claramente el viajero alemán Alejandro de Humboldt, en su Ensayo Político sobre el Reino de la Nueva España (1803), que en América "la piel, más o menos blanca, decide el rango que ocupa el hombre en la sociedad". ${ }^{18}$

\section{Los cuadros de castas: un programa iconográfico.}

\section{Los cuadros de castas se plantean como un programa iconográfico en el que además de las diversas combinaciones}

\footnotetext{
${ }^{16}$ La calidad se evidencia como entramado de valores que permite elaborar un juicio sobre una persona y mediante éste se asienta su ubicación en las relaciones jerárquicas de la sociedad; la calidad estaba condicionada por los factores color de piel, pureza y raza, pero también por los espacios del valor económico e institucional, los cuales tuvieron un impacto a la hora de performar la distinción social. La calidad debía ser custodiada y puesta en escena socialmente. La Limpieza de sangre está vinculada con el linaje y es tan solo un elemento de la calidad, que es una categoría más convencional y social (Véase: Hering Torres, Max S. "Color, pureza, raza: la calidad de los sujetos coloniales”, En: Heraclio Bonilla, (Ed.): La cuestión colonial. (Bogotá: Universidad Nacional de Colombia, 2011); 451-70.

${ }^{17}$ Creada en el siglo xv (1449), la política de la limpieza de sangre sirvió en España, Portugal y también a parte de Italia para poder marginar a moriscos y judeoconversos y proteger así a los cristianos viejos, que por generaciones habían mantenido la sangre sin mácula, limpia, sin mezcla alguna de sangre con judíos ni con moriscos; posteriormente, en América se utilizó el sistema para segregar a indígenas, mestizos, mulatos y otras castas. El Diccionario de Autoridades define la limpieza de sangre como: "la excelencia y prerrogativas que gozan las familias, aunque no sean nobles, y consiste en no tener mezcla de moros, judíos, ni herejes castigados (...) se llama también al sujeto que es christiano viejo de padres y abuelos, sin mezcla ni raza de Moros ni Judíos." (Diccionario de Autoridades, 1734: tomo IV, 409). (Véase: Hering Torres, Max S. "Color, pureza, raza: la calidad de los sujetos coloniales"... 466).

${ }^{18}$ Alejandro de Humboldt, Ensayo Político sobre el Reino de la Nueva España, (México: Porrúa, 1984), 90.
} 
de españoles, indios, negros y sus variopintas mixturas, ofrece la diversidad y la riqueza de la naturaleza novohispana representada en frutas, flores, verduras y animales. Además, procuran un acercamiento visual a la vida novohispana, particularmente el de la ciudad de México bajo el reformismo borbónico. ${ }^{19}$ Son en su mayoría ricos en detalles relacionados con diversos aspectos de la vida social y el quehacer cotidiano del siglo XVIII, en el "Teatro de las Maravillas", que es la capital novohispana (oficios, vestidos, viviendas, mobiliarios, alimentos, juegos, armas, joyas, libros, actitudes, lugares, ambulatajes, escenas domésticas y de taller o campestres, etc.), y destacan los productos exóticos del Nuevo Mundo ${ }^{20}$ y hasta remedios populares y de moda, como el chiqueador. ${ }^{21}$

\footnotetext{
${ }^{19}$ Ciudad de México con una población de 137.000 habitantes, se constituye en la más poblada urbe del continente, su población creció fuertemente a partir de la mitad del siglo XVIII. Las malas cosechas causaron una inmigración masiva de indios a la capital virreinal. Calcula Humboldt que 67,500 de sus habitantes son blancos $(49.27 \%)$ por residir en ella el gobierno Virreinal, 65.000 son criollos (47.44\%) y solo 2.500 son europeos (1.82\%). 69.500, la mayoría, son "hombres de color" (50.73\%); de ellos 33.000 son indígenas, cuya población se recupera durante el siglo XVIII (24.09\%), 26.500 son mestizos (19.34\%), y 10.000 son mulatos $(7.30 \%)$ y no nombra a los negros. Sostiene que en todas las colonias de los europeos, es en la Nueva España donde hay menos negros. Alejandro de Humboldt, Ensayo Político... 129.

20 Juan de Viera, criollo poblano, escribió en 1778 Breve compendiosa narración de la ciudad de México en el siglo XVIII, en el cual califica a la capital novohispana como "Teatro de las Maravillas", "Nueva Roma" y "Nueva Atenas", registra las innumerables mercaderías que se encontraban en la plaza mayor, incluyendo el nombre de 98 frutas, 42 tipos de pescado y mariscos y cientos de aves, afirmando que entre 2.000 y 10.000 canoas se utilizaban para proveer a la gran ciudad. Juan de Viera, "Breve compendiosa narración de la ciudad de México en el siglo XVIII", En: La Ciudad de México en el siglo XVIII (1690-1780): Tres crónicas, edición de Antonio Rubial, (México: Conaculta, 1990), 281.

${ }^{21}$ El chiqueador era un redondel de tela o de terciopelo negro que se pegaban las mujeres en el rostro asemejando un lunar. Moda en la Nueva España del siglo XVIII, también se utilizaba como remedio popular contra el dolor de cabeza, además de servir para ocultar manchas o cicatrices. Es usado por distintas mujeres y niñas pertenecientes a todas las castas representadas en las dos series de Magón, con excepción de las negras. En la serie de Lorenzana aparecen 9 chiqueadores y en la serie atribuida a Magón aparecen 8.
} 
Todas las series de castas poseen un texto, contenido o no dentro de una cartela, el cual cataloga con precisión los dos personajes adultos y su producto, a la vez que enumera dándole un orden serial y, con ello, una jerarquización a la diversidad de mestizajes posibles. La pretensión ilustrada de dar a conocer y categorizar, lleva a que en varias de las series los productos de la tierra, sean también representados en el cuadro, debidamente enumerados e identificados.

A partir de la serie del arzobispo Lorenzana, realizada por Magón, titulada: "Calidades que de la mescla de/ Españoles, Negros, é Yndias, pro-/ceden en la América; y son como/Se siguen por los números" (Imagen 11), analizamos los procesos de hibridación y su categorización en tres subseries que están determinadas: la primera por los componentes español e indio; la segunda por los componentes español y negro; y la tercera, donde queda excluido el español blanco. El primer cuadro de todas las series parte de la unión de un español con una india -representada con elementos que evidencian su pertenencia a la nobleza indígena y su calidad: riqueza en su indumentaria, lujosas telas, tocados, joyas, pose erguida, etc.-, que producen al mestizo. Lo que evidencia que esta es la mezcla básica entre los integrantes de las dos repúblicas fundadoras del Nuevo Mundo $^{22}$ (Imagen 12). El segundo cuadro de las series, lo ocupa la unión entre español(a) y mestizo(a) que produce al castizo(a) -individuo que tiene tres abuelos españoles y uno indio-. Y en el tercer cuadro de las series, éste último al mezclarse nuevamente con español produce español(a);

${ }^{22}$ Desde los primeros años que siguen a la Conquista, se estableció una distinción jurídica entre dos sociedades, la República de los españoles y la República de los indios. La República de españoles nacidos en España o América, y la República de indios, contaban con estatutos jurídicos diferenciados, aunque económica, social y geográficamente diferentes, estaban sometidas a la Corona y la tutela de la Iglesia. Los negros, en condición de esclavitud, quedan fuera de estas repúblicas. 
cumple así la ruta social del blanqueamiento, cierra el ciclo del mestizaje, no tiene mancha, tiene nuevamente limpia la sangre de su componente indio aumentando su calidad $\mathrm{y}$ sus posibilidades sociales $\mathrm{y}$, así, torna adelante a blanco español. Estas tres primeras mezclas componen la primera parte de todas las series de pinturas de castas: 1) De Español, é Yndia,/ nace/ Mestiza. 2) Español, y Mestiza/ producen Castiza. 3) De Español, y/ Castiza, torna á/ Español. ${ }^{23}$

La segunda subserie la constituye la mezcla entre españoles y negros: aparece el tercer elemento básico de esta policromada paleta racial novohispana. El español no tenía prejuicios raciales en su vida sexual pero sí en la vida social, para la que usa el matrimonio. El cuarto cuadro corresponde a la mezcla de un español con una negra, generalmente ubicada en la cocina haciendo chocolate o pegándole con el molinillo al español (Imagen 13); o de una española con un negro, representación menos común, habitualmente vestido con atuendo de cochero, que producen al mulato(a) (Imagen 14). La mezcla del español con el negro, en condición de esclavitud, no tiene ninguna posibilidad de blanqueamiento, pues aun mezclándose los productos nuevamente con españoles blancos y disminuyendo por ello el porcentaje de sangre negra, esta parte de la serie en la Nueva España luego de producir morisco(a) y albino(a) siempre termina en Torna Atrás. Comparándolo con la primera parte de las mezclas, el morisco -con tres abuelos españoles y uno negro- correspondería en porcentaje de sangre al castizo, que en la siguiente mezcla con español vuelve a ser blanco, sin embargo, morisco con español produce otra categoría racial nueva: el albino, que en contradicción con su nombre (representado colorísticamente como "más que blanco" y evidenciando su dificultad visual por falta de pigmento

${ }_{23}$ Trascripción textual de las cartelas de los cuadros de Magón. 
en el iris) ${ }^{24}$ (Imagen 15), y aun mezclándose nuevamente con un español o con una española produce siempre el Torna Atrás, el Salta Atrás: 4) De Español, y Ne-/gra, sale Mulato. 5) De Español, y/ Mulata, sale/ Morisca. 6) De Morisco, y/ Española, Albi-/no. 7) De Albino, y/ Española, lo que/ nace Torna atras. ${ }^{25}$ Humboldt, observó la condición problemática y degradante de las mezclas con el elemento negro en la Nueva España:

Las castas, descendientes de los negros esclavos, están notadas de infames por la ley, y sujetas al tributo, el cual imprime en ellas una mancha indeleble, que miran como una marca de esclavitud transmisible a las generaciones más remotas. Entre la raza de mezcla, esto es, entre los mestizos y los mulatos, hay muchas familias que por su color, su fisionomía y modales, podrían confundirse con los españoles; pero la ley los mantiene envilecidos y menospreciados. Dotados estos hombres de color de un carácter enérgico y ardiente, viven en un estado de constante irritación contra los blancos. ${ }^{26}$

En las dos series de Magón, la tercera subserie, del cuadro 8 al 16, se caracteriza por la ausencia del español en las mezclas, representando la unión de negros, indios y castas, cuya calidad disminuye al tiempo que disminuye su blancura y su estatus social. ${ }^{27}$ Es la más abundante

\footnotetext{
${ }^{24}$ Albinismo es una anomalía genética en hombres y animales que causa la ausencia de pigmentación, dada por la melanina, en el iris de los ojos, la piel y el pelo. Es una enfermedad hereditaria, que aparece cuando los dos padres tienen el gen recesivo del albinismo, luego puede haber albinos entre los blancos, los negros y los indios, siendo arbitrario convertirlo en una categoría racial que comprueba el no retorno de la mezcla con el elemento negro.

${ }^{25}$ Trascripción textual.

${ }^{26}$ Alejandro de Humboldt, Ensayo Político... 72.

${ }^{27}$ La más temida de las mezclas, para los funcionarios de la Nueva España, era el que se daba entre los negros y los indios, al punto de que el virrey Martín Enríquez de Almanza (1568-1580) propuso al rey, que le solicitara al Papa la prohibición total de los matrimonios mixtos.
} 
Interdiscursividad en la serie de cuadros de castas atribuida al pintor..

y la que más variaciones de categorías presenta. La estigmatización racial y social se manifiesta mediante el empleo de nombres-categoría provenientes del vocabulario relacionado con animales o con su crianza como: calpamulato, lobo, jarocho (gato montés), cambujo (ave de plumas y carne negra) y coyote; o colores de caballos como albarazado (manchado de blanco), barcino (también se aplica a gatos y patos atigrados) y zambo; o con el nombre de árbol o de leña quemada como chamizo. ${ }^{28}$ Los cuadros de castas terminan en categorías muy particulares, que vencen su propio afán clasificador y categorizador, como No te entiendo, Sambahigo, Ahí te Estás y Tente en el Aire: 8) Mulato, e Yn-/dia, engendran/ Calpamulato. 9) De Calpamu-/lato, é Yndia, sale/ Givaro. 10) De Negro, é Yndia,/ sale Lobo. 11) De Lobo, é Yndi-/a, sale Cambuja. 12) De Yndio,/ y Cambuja, nace/ Sambahiga. 13) De Mulato, y Mestiza,/ nace/ Cuarteron. 14) De Cuarteron, y/ Mestiza/ Coyote. 15) De Coyote,/ y Morisca,/ Naze/ Albarazado. 16) De Albarazado,/ y Salta atrás, sale/ Tente en el Aire. ${ }^{29}$

Los marinos ilustrados Antonio de Ulloa y Jorge Juan en su obra: Relación Histórica de un Viaje a la América Meridional (1748) sostienen: "Estas son las Castas más conocidas y comunes; no porque dexe de haver otras muchas, que provienen de la unión de unos con otros, y son de tantas especies, y en tan grande abundancia que ni ellos saben discernirlas". ${ }^{30}$ En este testimonio se manifiesta el estado de confusión racial que existía en las sociedades americanas tras la mezcla de 16 generaciones de españoles, indios, negros y castas,

${ }^{28}$ Isidoro Moreno Navarro, "Un aspecto del mestizaje americano: El problema de la terminología", Revista Española de Antropología Americana, No. 4, (1969): 201-18.

29 Trascripción textual.

${ }^{30}$ Antonio Ulloa y Jorge Juan, Relación histórica de un viaje a la América Meridional [1746]. Tomo I, Cap. IV. (Madrid: Dastin, 2002). 
tres siglos después de la conquista. Confusión que además de darle colorido y peculiaridad a la variopinta sociedad americana frente a las sociedades europeas, carentes de castas, generaba serios problemas administrativos, pues la pertenencia a una de ellas determinaba la calidad, la vida y posibilidades de los individuos así como el pago de tributos, las oportunidades laborales, de matrimonio, el acceso a la educación y a cargos eclesiásticos, militares o administrativos, la manera de vestir y el uso de joyas y de armas. En el mismo sentido se manifiesta el obispo de Michoacán, Abad y Queipo, al poner en evidencia la conflictividad social que de la confusión racial dimana:

La población de Nueva España, se compone de tres clases de hombres a saber: de blancos o españoles, de indias y de castas. Yo considero que los españoles componen la décima parte de la masa total. Casi todas las propiedades y riquezas del reino están en sus manos. Los indios y las castas cultivan la tierra; sirven a la gente acomodada y solo viven del trabajo de sus brazos. De ello resulta entre los indios y los blancos esta oposición de intereses, este odio recíproco, que tan fácil nace entre los que lo poseen todo y los que nada tienen, entre los dueños y los esclavos [...] Los indios y las castas están en la mayor humillación [...] La Ley prohíbe la mezcla de castas; prohíbe también a los blancos establecerse en los pueblos de indios y a estos domiciliarse entre los españoles. ${ }^{31}$

Los conflictos de castas se exacerban desde el año 1640 (a partir de esta fecha los libros parroquiales empiezan a ser distintos en la ciudad de México para españoles, indios y castas), cuando se presentan varios levantamientos, tanto

31 "Informe del obispo y cabildo eclesiástico de Valladolid de Michoacán, Abad y Queipo, al Rey, de 1799”. En: Alejandro de Humboldt, Ensayo Político... 71. 
de indígenas (1624 y 1692 por escasez de trigo y maíz) como de negros (1611 por el maltrato y muerte de una esclava) que amenazan no sólo con destruir el orden colonial sino, además, con sustituirlo. Las castas urbanizadas están ante todo constituidas por pobres gentes que ejercen trabajos manuales considerados por las élites blancas como infames. Este conflicto administrativo y social se refleja en la vida cotidiana de las ciudades novohispanas, que siguen creciendo y se siguen mezclando. ${ }^{32}$ Sin embargo, las pragmáticas reales de 1771, permitieron una salida, que tanto negras como mulatas, a las que la legislación colonial prohibía usar vestidos lujosos y joyas, las usaran, pero solo si estaban casadas con españoles. ${ }^{33}$ Fray Francisco de Ajofrín, en su Diario del viaje a la Nueva España (17631766), aclara: "La demás gente pobre viste como puede; regularmente, los descalzos venden zapatos y los desnudos venden vestidos." 34

Cuatro años después de la expulsión de los jesuitas, en 1771, el rey aprobó una nueva distribución parroquial para la Ciudad de México, que además de quitarle el control de las parroquias a las órdenes religiosas, terminaba con la separación racial por parroquias y zonas urbanas entre españoles e indios, iniciada en el siglo XVI, aumentando la confusión socio-racial. ${ }^{35}$

\footnotetext{
${ }^{32}$ Humboldt cuenta que a los mestizos "se les tiene por mucho más dulces de genio que los mulatos, que son los hijos de blancos y de negras y que se hacen distinguir por la violencia de sus pasiones y por una particular volubilidad de su lengua." Sostiene que la falta de vivacidad del indio mexicano, "su flema exterior", hace que: "las mujeres indias prefieren a los negros, no sólo a los hombres de su propia casta, sino aún a los europeos". En: Alejandro de Humboldt, Ensayo Político... 90 y 62.

33 Nicolás León, Las castas de México Colonial o Nueva España. (México: Talleres Gráficos del Museo Nacional de Arqueología, 1924), 9-10.

34 Fray Francisco de Ajofrín, Diario del viaje a la Nueva España, (México: Secretaría de Educación Pública, 1986). 68.

35 Juan de Viera. La Ciudad de México... 27.
} 
En la segunda mitad del siglo XVIII, la Corona dicta una serie de medidas de obligado cumplimiento para sus colonias, que inicialmente estaban destinadas a tratar de "ordenar" la confusión racial y el conflicto social. Todas estas medidas están recogidas bajo el título de "Pragmática Sanción para evitar el abuso de contraer matrimonios desiguales", de 1776. Esta "Real pragmática de casamientos", se aplica dos años después en Nueva España, e intenta proteger la blancura, controlar los matrimonios racialmente desiguales, ponerle freno al mestizaje y reforzar la autoridad paterna. La pragmática colocó a los funcionarios de la Corona de parte de las élites blancas, al darle poder de veto a los padres sobre el matrimonio de sus hijas e hijos, si el futuro cónyuge tenía "defectos como ilegitimidad o color quebrado". La Corona invade así un terreno antes exclusivo de la Iglesia. No obstante, esta Real Pragmática aplica para los blancos, los mestizos, los castizos y los indios; y no aplica, hasta 1803, para "mulatos, negros, lobos, e individuos de castas y razas semejantes", a quienes se les prohíbe habitar en los pueblos de indios. La finalidad inicial de la pragmática fue proteger la blancura, mientras las castas podían casarse sin problemas entre sí. ${ }^{36}$

Posteriormente, y en aparente contradicción con la Real pragmática de casamientos, España acuciada por problemas económicos por su guerra con Inglaterra, va a legislar en 1794 y 1795, dos reales cédulas, la primera de ellas en la que declaraba que los expósitos podían acceder a privilegios reservados, hasta ese momento, a los hijos legítimos; y la segunda, establecía los aranceles para "las gracias al sacar", sistema de ascenso social, mediante el cual mulatos y pardos podían comprar la blancura legal y así convertirse en personas honorables, la sentencia

${ }^{36}$ Véase Manuel Lucena Giraldo, Naciones de Rebeldes. Las revoluciones de independencia latinoamericanas. (Madrid: Taurus Historia, 2010), 48. 
proferida era: "téngase por blanco." Lo que se proyectó como medidas de orden y regulación de conflictos, terminó generando una reacción de descontento entre las élites blancas americanas, que observaban preocupadas cómo estas medidas iban en detrimento de sus privilegios raciales y sociales, poniendo en peligro su hegemonía. ${ }^{37}$

Los cuadros de castas cumplen con la exigencia de la Historia Natural del siglo XVIII en su afán de ordenar, comparar, clasificar y sistematizar los productos del Nuevo Mundo, incluidos como productos la propia sociedad de castas. En este sentido, y curiosamente coincidiendo con las Reformas Borbónicas, se constata la mayor proliferación de los cuadros de castas (década de los 70 y 80 siglo XVIII). ${ }^{38}$ iSon, entonces este tipo de pinturas respuesta a estas medidas? Inicialmente podríamos afirmar que no, ya que a finales del siglo XVII aparecen las primeras series. ${ }^{39}$ No obstante, existe una cierta vinculación entre el apogeo productivo de estas pinturas y el reformismo borbónico. Apogeo que constituye una manifestación de sensibilidad ante un clima social marcado por la confusión racial.

\footnotetext{
${ }^{37}$ Humboldt afirma que en la Nueva España, la riqueza y el lujo, proveniente de las minas de plata, se acrecentaron en los últimos años del siglo XVIII, riqueza en manos de la casta de los blancos; resalta también las enormes disparidades de riqueza que existen entre la élite blanca y "el populacho", que vivía en condiciones de miseria. Alejandro de Humboldt, Ensayo Político... 48 .

38 Katzew, no ve en la pintura de castas un género monolítico y encuentra diferencias entre las series de la primera mitad del siglo y las aparecidas en la época de auge. Su desaparición en el XIX está ligada al rechazo de la estructuración jerárquica de la sociedad colonial de castas, después de la guerra de independencia de México en 1810 y de la abolición del sistema gremial en 1813. (La pintura de castas, opus cit., p. 63).

${ }^{39}$ Teresa Castello señala que la colección más antigua de castas se encuentra en Inglaterra, donde llegó a finales del siglo XVII, capturadas por el almirante Westrow a un galeón español, compuesta por 14 cuadros, pintados sobre lienzo y enmarcados en molduras de madera de ébano. "La indumentaria de las castas del mestizaje", en: La pintura de Castas, Artes de México No. 8, (México: 1998); 72-8.
} 
También queremos señalar cómo precisamente las dos series de Magón pertenecen a este periodo. Y, en particular, la serie atribuida en la que los textos literarios incluidos en las representaciones, enjuician el carácter moral y social de las castas, ayudando a sostener las diferencias que se pretenden mantener. Como afirma Anne Ebert:

Lejos de poder comprender estos cuadros como simples representaciones del espíritu ilustrado de la época y la realidad colonial tardía, hay que comprenderlos como representaciones coloniales, y en este sentido no son "inocentes": ellos se (re) producen dentro de relaciones de poder, no sólo entre colonizados y colonizadores sino, además, dentro de las sociedades coloniales..$^{40}$

Son representaciones que contribuyen a la construcción, normalización y legitimación de diferencias socioeconómicas, como sostenidas en diferencias raciales: una naturalización de los órdenes sociales construidos históricamente. ${ }^{41}$ Existe una doble pretensión: de un lado, las mezclas para las cuales es posible el blanqueamiento; y, de otro, las que no pueden aspirar a ello, que son estigmatizadas. Esto evidenciaría a su vez, una doble posición en la que se situarían social e ideológicamente los criollos con respecto al mestizaje. Ya que al estar en la cumbre de la pirámide socio-racial colonial, al lado de los españoles peninsulares en condición de igualdad racial, y, a pesar de ello, luchando por sus derechos civiles y administrativos; a su vez, se sentían amenazados por un régimen colonial que, en aras de sus intereses económicos, había favorecido el ascenso social de las castas ${ }^{42}$ con medidas como las "gracias al sacar".

\footnotetext{
${ }^{40}$ Anne Ebert, "La representación de las américas coloniales en los cuadros de castas", Revista Scientia Vol. X: No. 10, pp. 139-152. p. 150.

${ }^{41}$ Anne Ebert, "La representación de las américas... 139.

${ }^{42}$ Pardos, negros libres y castas fueron incluidos en las milicias, la armada, las universidades y los protomedicatos de la Nueva España, con las reformas borbónicas.
} 
Es importante anotar que en estos cuadros de castas siempre se representa "al español blanco" y nunca se hacen diferencias de lugar de origen, es decir, no se habla ni de españoles peninsulares (gachupines), ni de españoles americanos (criollos). ${ }^{43}$ Hay por tanto, una pigmentocracia, es decir, el color de la piel justifica la condición social, lo más blanco está situado en la cumbre de la pirámide social y lo más mezclado al otro extremo, el extremo inferior de lo innombrable; la calidad de español y la blancura acompañadas del lujo y la riqueza, mientras la pobreza acompaña a los mezclados, a los descastados. Los cuadros de castas construyen las diferencias entre los cuerpos: nominalmente, taxonómicamente, estéticamente y moralmente: el temperamento como condición natural, como destino moral, como estática en la comprensión de los seres humanos, que se opone a la dinámica social que generan el trabajo, las mezclas y el enriquecimiento.

\section{La interdiscursiva serie de castas atribuida a José Joaquín Magón.}

José Joaquín Magón nació en Puebla de los Ángeles, donde trabajó en pintura de temas religioso y mitológico a partir de mediados del siglo XVIII. En 1760 hizo el arco triunfal para la jura del rey Carlos III en Puebla y en 1761 contrató la pira dedicada a la Reina Amalia de Sajonia. Posteriormente reside y trabaja en la Ciudad de México. Casó en 1778, en la parroquia de la Santa Cruz y Soledad de esta ciudad. Un documento inquisitorial, fechado en febrero de 1783, registra un episodio de su vida que lo describe como un

43 Sobre los criollos dice Humboldt que "prefieren que se les llame americanos"; agrega, que en México, con 135.000 habitantes solo 2.500 son nacidos en Europa, la proporción entre europeos y criollos blancos es de 1 a 14, existiendo una rivalidad endémica entre criollos y gachupines. Alejandro de Humboldt, Ensayo Político... 78. 
personaje atrevido y violento; ${ }^{44}$ siendo procesado por el Tribunal del Santo Oficio de la Inquisición por blasfemias hereticales en $1783^{45}$, cuando fue encarcelado por molestar a su mujer y escandalizar a sus vecinos. ${ }^{46}$

La serie atribuida a Magón, que lleva por título: "En la America nacen gentes diversas/ En color, en construmbres/ Genios y lenguas", está compuesta por 16 cuadros establecidos en el siguiente orden numérico, en el que se incluye la leyenda literaria que los caracteriza ${ }^{47}$ :

I. Del Español y la Yndia/ nace el Mestizo/ por lo común humilde/ quieto y sencillo.

II. Mestizo y Española/ dan al Castizo/la afición al Caballo/desde bien niño.

III. De Español y Castiza/ el fructo bello/ se ve igual a su Padre/ ya pelo a pelo.

IV. El orgullo y despejo/de la Mulata/ nace del Blanco y Negra que la dimanan.

V. Español, y Mulata/ ser y doctrina/ dan conforme a su genio/ a la Morisca.

VI. De Español y Morisca/ nace el Albino/ corto de vista, devil/ suave, y benigno.

VII. Albino y Española/ los que producen/ de torna atrás en figura/ genio, y costumbres.

VIII. Mulato e Yndia engendran/ calpa Mulato/ de indocil genio, fuerte/ cuerpo cortiancho.

IX. De Yndia, y Calpamulato/ Gibaro nace/ inquieto de Ordinario/ siempre arrogante.

\footnotetext{
${ }^{44}$ Guillermo Tovar y De Teresa, Repertorio de artistas en México, T. II, (México: Bancomer 1996), 292.

45 Efraín Castro Morales, "Notas", en Bernardo Olivares Iriarte, Álbum artístico, (Puebla: Secretaría de Cultura del Estado de Puebla, 1987), 148.

${ }^{46}$ Efraín Castro Morales, "Notas"...

${ }^{47}$ Serie de Pintura de Castas compuesta por 16 cuadros pintados al óleo sobre tela, de 102 por $126 \mathrm{~cm}$, sin fecha y sin firma, pintada en la Nueva España, atribuida por García Sáiz a José Joaquín Magón. Los cuadros de la serie de Lorenzana son más grandes, miden 115 por $141 \mathrm{~cm}$.
} 
X. De Negro e Yndia, Lovo/ mala ralea/Herodes son de bolsas/ y faltriqueras.

XI. Lovo e Yndia, Cambujo/ es de Ordinario/ pesado, y perezoso./ de ingenio tardo.

XII. El Yndio y la Cambuja,/Sambayga engendran/ elq' no ai Maturranga/ que no lo Entiendan.

XIII.El Cuarteron capcioso/ a luz dimana/ del Mestizo sencillo,/ y la Mulata.

XIV.Cuarteron y Mestiza/ siempre peleando/ engendran al Collote/ fuerte y osado.

XV. De Collote y Morisca/ el Albarazado/ nace, y se inclina siempre/ á burlas y chascos.

XVI. Tenteenelayre, nace/ (ingerto malo)/ De Tornaatrás adusta/y Albarazado. ${ }^{48}$

La diversidad y riqueza de la naturaleza novohispana está presente en todos los cronistas de la época, en todas las series de cuadros de castas y en las dos series de José Joaquín Magón. Las verduras, las frutas y los vegetales son representados en casi todas las pinturas de las dos series haciendo parte de la escena, o aun colgando de las cartelas. Destaca la presencia de aguacates, elotes, repollos, tomates, zanahorias, calabazas, ahuyamas y ajíes, generalmente en la cocina. También se identifican papayas, higos, uvas, cítricos, además de plátanos, sandías, mameyes, zapotes, guanábanas y anones, que confirman la abundancia de la Nueva España y que hacen parte de la lista de las 98 frutas, que según Juan de Viera, se venden en el mercado de México. En la serie de Lorenzana solo en el cuadro 15 no aparecen los productos de la tierra y en la serie atribuida a este elemento se le da menos importancia y, por tal razón, no aparece representado en los cuadros I, III, V y XIV.

Humboldt relata que en el gran mercado de México, en el que en un día común había 60.000 personas entre

48 Transcripción literal. Ortografía según el original. 
compradores y vendedores, se daba el arte de entretejer las flores y los frutos, cuenta que no se venden los productos del país, melocotones, piñas, legumbres, "ni aún el pulque, sin adornar su tienda de flores, renovándolas todos los días", contando además, que Cortés ya había observado el gusto por las flores en la corte de Moctezuma. ${ }^{49}$ Este gusto por las flores se aprecia en la obra de Magón, que pinta azucenas, crisantemos, cayenas, nardos y otras coloridas flores de la Nueva España, sobretodo en la serie de Lorenzana, en la cual solo 2 cuadros carecen de ellas, mientras que en la serie atribuida están representadas en apenas 5 cuadros, sin contar que en ocasiones las flores aparecen representadas indirectamente en los diseños de las telas de los vestidos.

En los animales representados en las 2 series predominan las aves. Muchas de estas, además de representar la diversidad de la fauna local han sido tradicionalmente usadas como símbolos. Katzew relaciona los loros con "la fidelidad y constancia marital"50, las palomas en la tradición cristiana han sido vinculadas a la paz, el amor y el descanso y, en Mateo 10:16, Jesús las menciona como símbolo de la sencillez. Magón pinta en las dos series una pareja de palomas, blanca y gris, una frente a la otra, que acompañan en la serie de Lorenzana al mulato zapatero y a la mujer mestiza limpiando al niño cuarterón, en una escena de intimidad, armonía, trabajo, amor y sencillez; en la serie atribuida aparecen las mismas palomas, que del centro pasan a las esquina inferior izquierda para equilibrar la composición, ambas en primer plano, acompañando al indio y la cambuja que juegan pirinola y apuestan cascabeles aztecas ${ }^{51}$, mientras

\footnotetext{
49 Alejandro de Humboldt, Ensayo Político... 65.

${ }^{50}$ Ilona Katzew, La Pintura de Castas.... 109.

${ }^{51}$ Los cascabeles de hilo de la región tarasca del centro de México, eran pequeñas piezas de orfebrería (cobre y plata), trabajadas a la cera perdida, siendo los artefactos metálicos arqueológicos más abundantes en Mesoamérica.
} 
la pequeña sambahiga, producto de su unión, los distrae del juego. En la serie de Lorenzana se representan loros, palomas, pavos, garzas, petirrojos y patos y en la serie atribuida: gallo de pelea, cambujo, pescados y caballo.

En las dos series de 16 cuadros, Magón representa los mismos cruces en escenas cotidianas, teniendo el cuidado de no repetirse. En la serie de Lorenzana aparecen escenas generalmente de trabajo en talleres, ventas ambulantes, o en interiores como la cocina o el estudio: escribano, bordadora y vendedor ambulante de telas, cocinera, miliciano, sastre, fabricante de cigarrillos (Imagen 16), jugadores de cartas, vendedoras de frutas y de tortillas de maíz, cochero, hilandera (Imagen 17), zapatero, vendedor de objetos de hierro y zurcidor de medias. Estas escenas detallan, tanto el lugar como el quehacer y las herramientas de trabajo y las personas aparecen involucradas en los oficios. En el último cuadro solo se representa la pelea entre la pareja, y como en el primero, no se muestra ningún oficio. Evidencia esta serie, una frescura y naturalidad afectuosa en el tratamiento de las escenas cotidianas que la caracterizan (Imagen 18). En la serie atribuida los oficios ya no tienen la importancia ni en el número ni en la definición de detalles, que se les da en la serie de Lorenzana. Por el contrario, en la serie atribuida disminuyen los oficios mientras los juegos y el entretenimiento aumentan. Desaparece el cuidado en la representación del taller artesanal y de las ventas ambulantes: el trabajo, su lugar, sus quehaceres y herramientas ya no son prioritarias para el pintor ni, evidentemente, para el cliente. El énfasis que pone Magón en la serie atribuida, coincide con las Reformas Borbónicas destinadas al control y persecución de los juegos de azar en el territorio novohispano. ${ }^{52}$ Otras actividades perseguidas

${ }^{52}$ En 1745 el rey de España emitió un real decreto prohibiendo todos los juegos de azar, naipes, dados y apuestas, en las Indias, porque fomentaban el vicio y el ocio. 
por estas reformas, y a las que la serie atribuida le presta atención fueron el baile, el alcohol, la pereza, el robo, la violencia y las armas. Las leyendas que aparecen en las cartelas de esta serie refuerzan un carácter moralizante, en coincidencia con las Reformas Borbónicas.

En la serie atribuida, solo se representan oficios en 6 cuadros y en algunos de ellos no es claro si es una actividad doméstica o se trata de un trabajo artesanal. De estos, 2 aparecen con uniformes de milicianos, un español y un calpamulato, cuyo acceso a las milicias fue resultado del ascenso social de las castas generado por las Reformas Borbónicas; uno aparece cortándole el pelo al hijo; otra es la negra cocinera; y, por fin, el español del segundo cuadro que parece tener herramientas de carpintería. Las ocupaciones representadas en la serie atribuida, se pueden resumir así: el español y la india se representan en una escena domestica sin oficio (I), mestizo: aparentemente carpintero (II), español: escribiente (III), negra cocinera (IV), español tocando guitarra y mulata y su hija morisca bailando (V), español miliciano (VI), escena de bebida (albino y española) (VII), no hay elementos para definir un oficio (VIII), calpamulato, miliciano de caballería (IX), india moliendo y negro, al parecer tomado, pereceando (X), lobo con bolsa cortada e india atajándolo (XI), indio otomí y cambuja jugando a la pirinola (XII), mestizo peluquero (XIII), mestiza atajando al cuarterón que va armado con una daga (XIV), collote y morisca jugando a las damas (XV) y tenteenelayre y torna atrás, elaborando un arreglo que entreteje frutas y flores (XVI).

En la serie atribuida, aparecen representados tres juegos: dos escenas explícitas, juego de pirinola y de damas, además de un gallo de pelea. A partir de la segunda mitad del siglo XVIII, en el marco de las Reformas, aparece un gran número de reales cédulas, autos, decretos, bandos, pastorales y edictos de la Inquisición que tratan de remediar el problema social del "relajamiento de las 
costumbres". Entre las actividades que se quieren combatir están los juegos de azar (Imagen 19), la lascivia (Imagen 20), las embriagueces públicas (Imagen 21), las riñas en las pulquerías, los desórdenes y las diversiones callejeras, que se quieren controlar y reglamentar. En particular, los juegos de azar eran considerados como unas de "las plagas sociales" con perniciosos efectos, una fuente de vicios, desnudeces, ocios y delitos, por tanto, uno de los factores principales de la preocupante relajación de las costumbres novohispanas. Los viajeros observan la pasión de los naturales por los juegos de azar, vivida al igual por hombres, mujeres y niños. Estos juegos fueron tolerados hasta la primera mitad del siglo XVIII pero entre 1747 y 1800, fueron publicados diez bandos de los virreyes controlándolos mas no prohibiéndolos e incluyéndolos, al legalizarlos, como fuente de recursos para la Real Hacienda. ${ }^{53}$

\section{Discusión y acertijos.}

En el primer apartado de este trabajo hemos recordado la contradicción puesta de manifiesto por García Sáiz, entre lo que dicen las leyendas literarias y lo que representa en si la escena; por ejemplo:

Es difícil imaginarse al lobo como de "mala ralea, Herodes de bolsas y faltriqueras", cuando se nos representa como un pequeño que reprocha a su padre, negro, que esté dormitando sin hacer nada mientras su madre se afana en las tareas caseras, o al tente en el aire, que ayuda a sus padres a confeccionar un adorno floral, como "ingerto malo". ${ }^{54}$

\footnotetext{
53 Teresa Lozano Armendares, "Los Juegos de Azar, ¿Una Pasión Novohispana Legislación sobre juegos prohibidos en Nueva España, siglo XVIII", Estudios de Historia Novohispana, Vol. 11: No. 011 (1991):155-181. ${ }^{54}$ María Concepción García Saiz, Las castas mexicanas... 102.
} 
Tomando en cuenta las palabras de la historiadora del arte española, llama la atención que el producto del cuadro X (Imagen 3) es decir, el "lovo", es el progenitor en el cuadro XI (imagen 7), de tal manera que la leyenda del cuadro X, "Mala ralea, Herodes son de bolsas y faltriqueras", tiene sentido solamente cuando se le aplica al progenitor del cuadro XI, ya que Magón decidió representarlo como un "Herodes de bolsa y faltriquera": véase en la imagen como el progenitor lovo, porta en su mano izquierda una bolsa recién cortada, probablemente con el cuchillo que porta en su mano derecha. ¿La leyenda del cuadro $\mathrm{X}$, representada escenográficamente en el cuadro XI, es una anticipación sobre el estigma social que determina el destino del producto del cuadro X? Aparentemente sí. De esta manera, la contradicción que encuentra García Sáiz quedaría resuelta al entender ambas pinturas como referenciadas entre sí. De tal manera que siguiendo la secuencia numérica de toda la serie que va de la I a la XVI, al llegar al cuadro X, nos encontraríamos con que el "acertijo", que plantea la leyenda de este cuadro, se resuelve en la representación escenográfica que vemos en el cuadro XI de la serie atribuida.

El segundo caso propuesto por Garcia Sáiz, es decir: "al tente en el aire, que ayuda a sus padres a confeccionar un adorno floral, como "ingerto malo"; la leyenda, a la que pertenece la cita: "Tenteenelayre, nace/ (ingerto malo)/ De Tornaatrás adusta/y Albarazado", debe seguir entendiéndose como un "acertijo", sin solución escenográfica pero con condena y estigmatización social y cultural de carácter hereditario. No tiene solución escenográfica, como en el caso anteriormente descrito, porque todas las series novohispanas están compuestas de 16 cuadros. De esta manera y, contrariamente a como ocurrió en el caso antes explicado, el "Tenteenelayre", es decir, el "ingerto malo" no se va a desarrollar como adulto en ninguna escena número XVII, ya que esta escena no existe. Así, 
el espectador del cuadro encontrará en esta escenificación del tenteenelayre como niña, una posibilidad abierta que nunca escenográficamente queda resuelta al convertirse la niña en adulta. La niña, según la leyenda, llevaría en su ser el hereditario e imborrable estigma de "ingerto malo", pero precisamente se presenta solo como injerto al no poder el observador comprobar el posible fruto al no existir el cuadro XVII. A pesar de que el injerto nunca va a ser representado como "árbol que de sus frutos", la leyenda ya promulgó una sentencia condenatoria sobre el futuro de esta niña. En definitiva, estamos ante un planteamiento interdiscursivo entre la leyenda literaria y la escenografía pictórica. Planteamiento que lejos de contradecirse se presenta y re-presenta como acertijos, como enigmas, como divertimentos, como albures, que el espectador debe tratar de resolver en su aparente contradicción, todo ello dentro de una retórica de tradición barroca que estaría en consonancia con el gusto de la sociedad criolla blanca del virreinato de la Nueva España. Solange Alberro, señala al respecto, que los criollos eran retóricos, rebuscados, usaban las sutilezas del silogismo, eran totalmente barrocos en el lenguaje, recordando la estética que adornaba las fachadas y las iglesias novohispanas. Los criollos hacían mucho esfuerzo en no decir nada con sencillez y naturalidad, usando metáforas y circunloquios floridos frecuentemente. ${ }^{55} \mathrm{Si}$ bien estas pinturas se limitan a 16 posibilidades de híbridos, el crisol socio-racial es infinito, aunque este discurso, de raíz sistemática y clasificatoria muy acorde con el discurso de la Historia Natural ilustrada imperante en el momento, no es capaz de nombrar la hibridez más allá de estas 16 categorías; estando en consonancia con otros sistemas clasificatorios que la Historia Natural había puesto en juego. De tal manera que, aun sabiendo que esta hibridez es infinita

${ }_{55}$ Solange Alberro, Del gachupín al criollo. O de como los españoles de México dejaron de serlo, (México: El Colegio de México, 2002): 216-18. 
como instrumento que trata de controlar y sistematizar la variedad, sólo se remite a los tipos más representativos.

Igual sucede con el cuadro XIII (imagen 9) de la serie atribuida a Magón cuya leyenda reza: "El Cuarterón capcioso/ a luz dimana/ del Mestizo sencillo,/ y la Mulata”, en el cual se representa al cuarterón siendo peluqueado por su padre mestizo, mientras la madre mulata, con una cesta de frutas en su brazo, sostiene un pequeño espejo en el que se mira el cuarterón. Capcioso ${ }^{56}$ significa falaz, embustero y falso y, cuando está referido a una pregunta, argumentación o sugerencia alude a las estrategias tramposas "que se hacen para arrancar al contrincante o interlocutor una respuesta que pueda comprometerlo, o que favorezca propósitos de quien las formula". La actitud tranquila y el gesto descomplicado del pequeño cuarterón, serían contradictorias con lo expresado en la leyenda. La única alusión al engaño implícito en la leyenda, estaría en la presencia en la pintura del espejo, elemento muy apreciado por la estética barroca que nos remite, tanto a sus imágenes como a lo que ve quien en este se mira. Es decir, que siempre ha sido un símbolo del problema humano del conocerse a sí mismo y de la identidad. Pero, además, como en los cuadros anteriores, la leyenda de este cuadro XIII adquiere su pleno sentido solo en el cuadro XIV (Imagen 5): "Cuarterón y Mestiza/ siempre peleando/ engendran al Collote/ fuerte y osado". En este cuadro aparece el cuarterón ya adulto, como progenitor del collote, en una escena exterior, con una expresión desesperada y una mirada fija, tiene un puñal fuertemente asido en su

${ }^{56}$ Según el Diccionario de la RAE: Capcioso, sa. (Del lat. captiōsus). 1. adj. Dicho de una palabra, de una doctrina, de una proposición, etc.: falaces ( $\square$ embusteras, falsas). 2. adj. Dicho de una pregunta, de una argumentación, de una sugerencia, etc.: Que se hacen para arrancar al contrincante o interlocutor una respuesta que pueda comprometerlo, o que favorezca propósitos de quien las formula. Real Academia Española (RAE). Diccionario de la Lengua Española, decimonovena edición, (Madrid, 1983), 251. 
mano derecha y, en la izquierda, lleva su capa y sombrero, mientras su hija y su mujer intentan detenerlo. Igual que en el primer caso planteado por García Sáiz, el acertijo del cuadro XIII se resuelve como destino, como condena, en el adulto del cuadro XIV.

La condición de serie compuesta por los 16 cuadros permite que una leyenda, a manera de acertijo, por su aparente contradicción al referirse a un niño de una escenificación, adquiera sentido en el cuadro posterior donde tal niño o niña aparece ya como adulto. El carácter descrito en la leyenda y en aparente contradicción con el niño o niña, oficiaría como sentencia inexorable, como su ineludible destino, un estigma materializado en su etapa adulta. Esto se puede apreciar en el cuadro I de la serie atribuida: "Del Español y la Yndia/ nace el Mestizo/ por lo común humilde/ quieto y sencillo." (Imagen 22) En este cuadro el lujo de las vestiduras de sus tres protagonistas y el exclusivo aprendizaje y uso de la escritura y la lectura -el español está leyendo el Quijote, mientras la madre enseña una especie de plana y el mestizo ofrece a su padre un papel en donde se puede leer la palabra "Parco", muy seguramente complementando, por parte del pintor, el carácter del niño-, estos elementos contrastan con la caracterización de la personalidad del mestizo, que está propuesta en la cartela: humilde, quieto, sencillo -y parco-. Pero al observar los mestizos, ya adultos, que están representados en los cuadros II y XIII (Imagen 9), su humildad y sencillez se hacen evidentes, disolviéndose nuevamente la contradicción, el acertijo; esta vez, no sólo en el cuadro siguiente sino también en uno bastante posterior, donde vuelve a aparecer representado el niño mestizo como un adulto.

Esta continuidad nos permite esclarecer, así mismo, la condición de la mulata, quien es representada como niña en el cuadro IV: "El orgullo y despejo/de la Mulata/ nace 
del Blanco y Negra que la dimanan.” Donde aparece la niña en el regazo de su padre español blanco, mientras su madre negra, ataviada con collar y aretes bate el chocolate en medio de una cocina repleta de productos de la tierra. La niña representada con sencillez entra en aparente contradicción con el despejo y el orgullo de la leyenda. Contradicción-acertijo que se resuelve al ver la gracia, desenvoltura, agilidad, soltura y elegancia del vestido de la mulata que aparece danzando en el cuadro V (Imagen 10): "Español, y Mulata/ ser y doctrina/ dan conforme a su genio/ a la Morisca." Sorprende en este cuadro el cuidado del pintor para representar los vestidos y los accesorios que adornan, tanto a la mulata como a su hija morisca, mientras el español toca la guitarra. La mulata vuelve a ser representada en el cuadro XIII (Imagen 9) de la serie atribuida, como madre del cuarterón, elegantemente vestida, mientras sostiene el espejo, que también simboliza la vanidad, uno de los siete pecados capitales.

El mismo argumento puede aplicarse a la representación del albino. Este aparece como niño en el cuadro VI: "De Español y Morisca/ nace el Albino/ corto de vista, devil/suave, y benigno". Donde aparece representado irónicamente con uniforme de oficial de milicianos como su padre español, quien le está colocando su tricornio, mientras su madre morisca, le ayuda a sostener la escopeta. Como complemento del cuadro están en la esquina inferior derecha dos aves de caza: un pato y una codorniz. ¿Cómo una persona que es falta de vista, débil, suave y benigna se representa armada y con uniforme de miliciano o como dispuesto a ir de caza? ¡Qué peligro! Como en los anteriores casos, el acertijo, cargado de una especie de humor negro, se resuelve en el cuadro VII (Imagen 20): "Albino y Española/ los que producen/ de torna atrás en figura/ genio, y costumbres", en el cual el albino, ya adulto, le sirve una copa de vino a la española que se pinta con la mirada perdida y en actitud rendida, en la representación 
más erótica de las mujeres pintadas en las dos series de Magón. El cuadro es acompañado de un pavo, en primer plano, animal que se asocia usualmente con la lujuria y la lascivia, elementos que no están presentes en la serie del arzobispo.

Último ejemplo de estos acertijos es el del niño calpamulato del cuadro VIII: "Mulato e Yndia engendran/ calpa Mulato/ de indocil genio, fuerte/ cuerpo cortiancho", que aparece representado en el regazo de su madre india, casi desnudo mostrando la condición cortiancha de su cuerpo, mientras repite los gestos que con sus manos hace su padre mulato, que trae un gallo de pelea, en una canasta. El indócil genio que entra en contradicción con el niño juguetón, es un acertijo que se resuelve en el cuadro IX (Imagen 8): "De Yndia, y Calpamulato/ Gibaro nace/ inquieto de Ordinario/ siempre arrogante", donde el calpamulato, ya adulto, aparece como fuerte y corpulento miliciano de caballería, mientras su mujer india y su hijo jíbaro le alcanzan, en actitud sumisa, una su capa y, otro, su escopeta.

En contraposición con los anteriores cuadros de la serie atribuida a Magón, caracterizados por la contradicción y el acertijo que se resuelve en la representación escénica del siguiente cuadro, llama particularmente la atención el cuadro II: "Mestizo y Española/ dan al Castizo/la afición al Caballo/desde bien niño." El único cuadro que en su leyenda utiliza la palabra niño y habla del producto como niño, no se refiere a un destino a realizar en la vida adulta, sino a una característica que le transmiten desde niño sus progenitores, el español y la mestiza. En este caso, la representación es plenamente coherente con la leyenda sin entrar en contradicción los dos discursos. El niño castizo mantiene por las riendas, con su mano izquierda, un caballo de juguete y, en la derecha, sostiene una larga daga, mientras su madre española le coloca un gorro cónico 
muy adornado -a la usanza indígena- y lleva puesto un peto con una figura humana en la parte delantera, que complementa su atavío infantil de jinete.

También es significativo considerar el cuadro III (Imagen 23) de la serie atribuida: "De Español y Castiza/ el fructo bello/ se ve igual a su Padre/ ya pelo a pelo", que es final de la subserie entre españoles e indios, única donde, como ya se dijo, el blanqueamiento es posible. La españolita "fruto bello", que recupera la blancura y la pureza de sangre, se mira en el barroco espejo, mientras su madre, de tez más oscura, la peina, para verse pelo a pelo igual a su padre, ya no hay necesidad de representarla en el siguiente cuadro, se acaba la subserie, pues ya, la española-blanca, retorna a la cima de la pirámide socioracial colonial. El español aparece escribiendo, con el gorro que se ponían en casa cuando se quitaban la peluca, está acompañado de una biblioteca en donde se puede comprobar la existencia de tres tomos en cuyo lomo se puede leer "Theatro de Dios". ${ }^{57} \mathrm{Al}$ igual que en el primer cuadro, se evidencia que escribir y leer, tanto como el ocio y la calidad, son privilegios de la blancura.

\section{Conclusiones.}

Como hemos podido demostrar, la relación problemática entre la leyenda literaria y la representación pictórica, es más compleja que la simple contradicción planteada por García Sáiz. En primera instancia, es indispensable

\footnotetext{
${ }^{57}$ No nos fue posible encontrar una referencia bibliográfica que responda al título "Theatro de Dios", que llevan los tomos de la biblioteca del español; sin embargo, se encontró que, como concepto, está vinculado a la concepción que del Universo profesaba el reformador Calvino, en cuanto lugar en donde la gloria de dios se hace manifiesta. La implicación ética de este concepto, es que ello debería motivar a los seres humanos a ser "actores" dignos del "Teatro" donde actúan.
} 
considerar que José Joaquín Magón, es el único pintor de cuadros de castas, que nos permite, al comparar sus dos series, ver la radical novedad que implica agregarle en la cartela una leyenda literaria a lo que en las demás series se presenta como un rótulo exclusivamente enumerador y clasificatorio concordante con el ideal ilustrado de la Historia Natural. Cuando se mira la serie atribuida, los ojos van y vienen entre la representación pictórica y la leyenda literaria agregada en la cartela, obligando a quien ve a reconocer que no hay casualidad ni inocencia en tal agregado. Todo lo contrario, ella genera una profunda interferencia sobre el lenguaje pictórico, le pone condiciones al mirar del espectador, alterando y sesgando la posibilidad de ver lo representado por el pintor. A su vez, lo representado a través del lenguaje pictórico no se agota con el discurso impuesto por la cartela, el discurso pictórico se resiste al discurso literario al no ser una ilustración de lo escrito en la leyenda: contiene muchos más elementos, crea vacíos, confunde, entra en contradicción, genera preguntas y conflictos. Estamos ante un planteamiento interdiscursivo entre la leyenda literaria y la escenografía pictórica. Todo lo anterior nos ha llevado a considerar a la leyenda literaria como un acertijo, un enigma, un divertimento, un albur -figuras propias y representativas de la retórica barroca-, que no se resuelve en el propio cuadro, que solo adquiere sentido si se le da oportunidad a la ironía y si se ve la secuencialidad de la serie. Secuencialidad que en este caso supera la simple enumeración para convertirse en un discurso socio-racial, que interpreta la vida de sus protagonistas con la idea de un destino social y moral que procede del linaje y que al ser hereditario condena el futuro de una persona en una sociedad de castas.

La serie del arzobispo Lorenzana, muy llena de productos de la tierra, de oficios, de escenas domésticas, responde a la dinámica de la Ilustración entre el afán de 
conocimiento y el gusto por la diversidad y el exotismo de los nuevos mundos. Funciona, por tanto, como souvenir, como muestra para ser exhibida en el Viejo Mundo en algún gabinete de Historia Natural, precursores de los actuales museos, donde el orden social, como parte del orden natural, es sometido a la misma manía clasificatoria, generando un orden que jerarquiza y, con ello, califica y descalifica.

Por su parte, la serie atribuida a Magón que se encuentra en México, al darle menos importancia a los elementos exóticos y a la representación detallada de los oficios, constituyentes del orgullo criollo novohispano y al tener un carácter claramente moralizante, parece ser realizada para un cliente de la élite blanca local y para una exhibición interna en la Nueva España; cliente interno que, amenazado por la dinámica socio-racial en sus privilegios y defendiendo su posición en la cumbre de la pirámide social, intervendría en el discurso pictórico, al incluir la leyenda literaria que genera la interdiscursividad analizada.

La noción de destino determinada por el color, la calidad y el linaje de los ancestros, es decir, la idea de una sociedad estática de castas, es contradictoria y va a ser impugnada por las ideas liberales e ilustradas, de libertad e igualdad, por una parte, y por el proyecto de perfectibilidad de la condición humana a través de la educación. El conflicto social de las castas, tan profusamente representado y descrito por funcionarios civiles y religiosos, cronistas, viajeros y pintores de cuadros de castas, no podía solucionarse con la Independencia y la legislación republicana, que solo acabaron con la posibilidad de representación pictórica, pero no con el problema racial y social. 


\section{Imágenes}

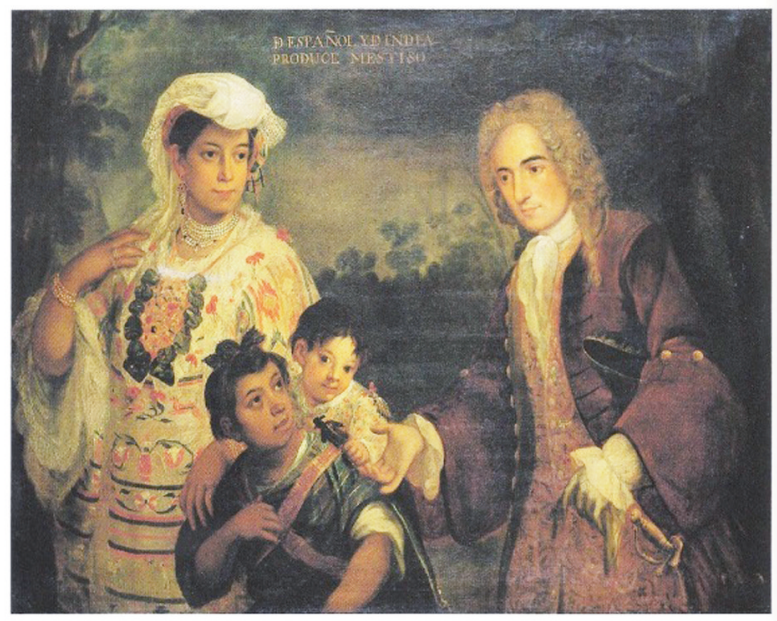

77 Attributed to fuan Rodiguez Juarez, De eppanol y de is:ata, produe mostiza (Spaniard and Indian Produce a Mestizo), a. :715, ol on crivas, $104.1 \times 147 \mathrm{~cm}$. Prinate collectron.

Imagen 1. De español y de india produce mestizo.

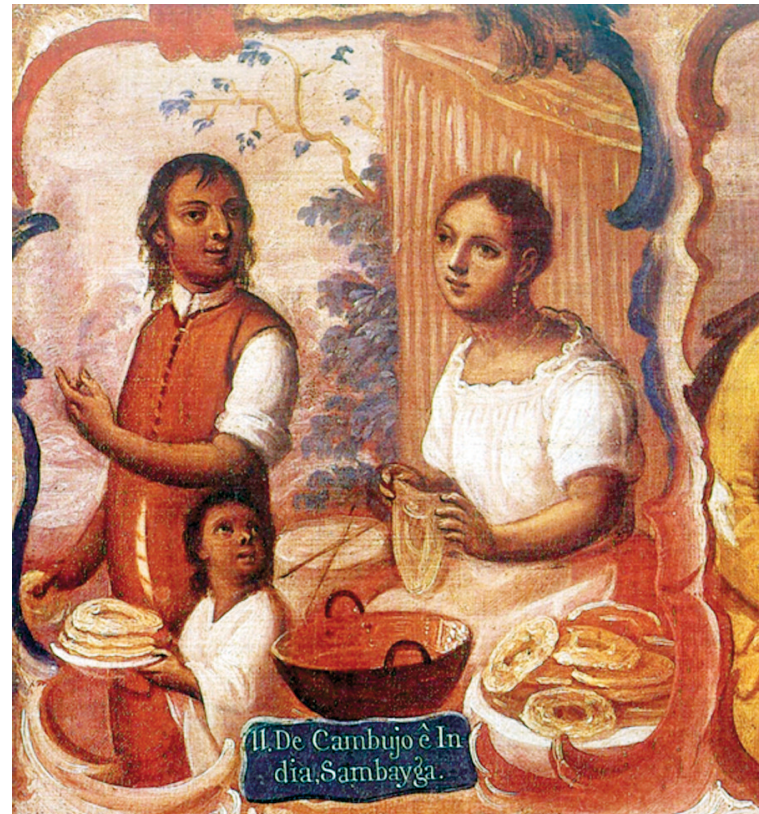

Imagen 2. De Cambujo e india, Sambayga.

Juan Rodríguez Juárez, 1715. José de Páez 1770-1780. 


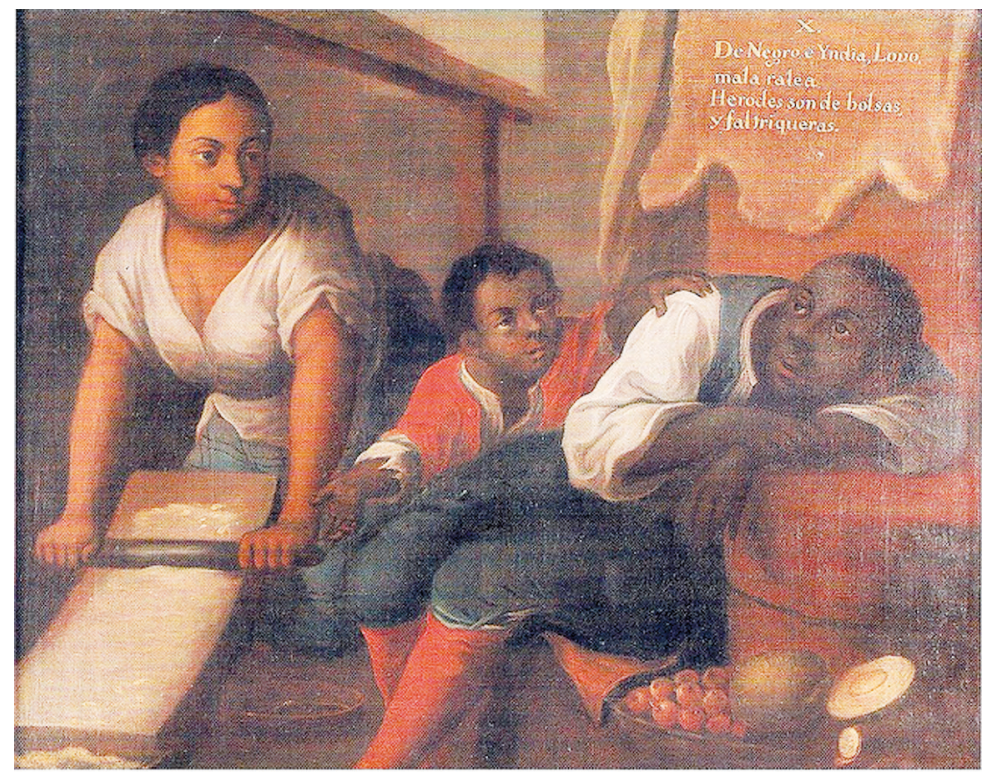

Imagen 3. De Negro e Yndia, Lovo / mala ralea /

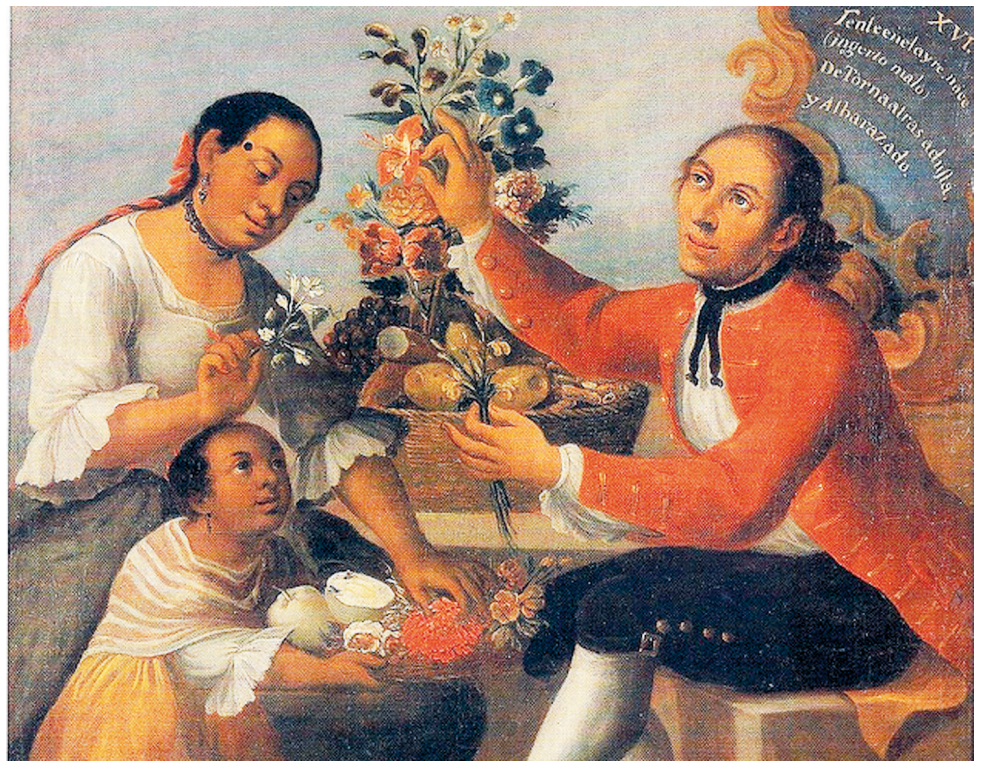

Imagen 4. XVI. Tenteenelayre, nace/ peleando/ Herodes son de bolsas/ y faltriqueras. (ingerto malo)/ De Tornaatrás adusta/y Atribuido a José Joaquín Magón. Albarazado. Atribuido a José Joaquín Magón. 


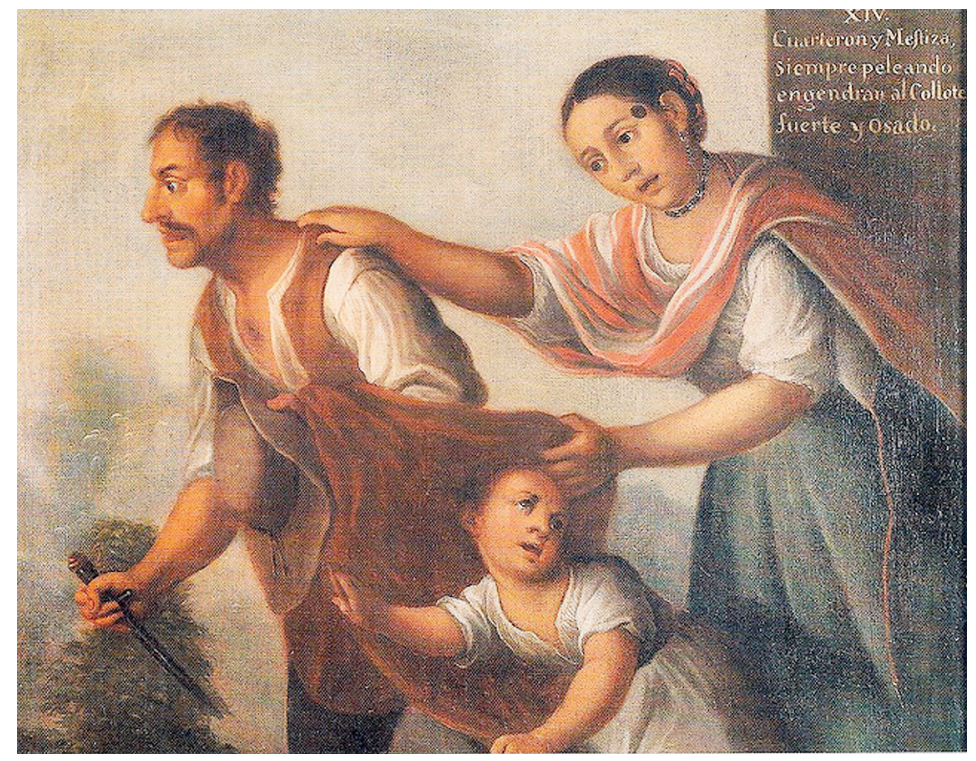

Imagen 5. XIV. Cuarteron y Mestiza/ siempre engendran al Collote/ fuerte y osado. Atribuido a José Joaquín Magón.

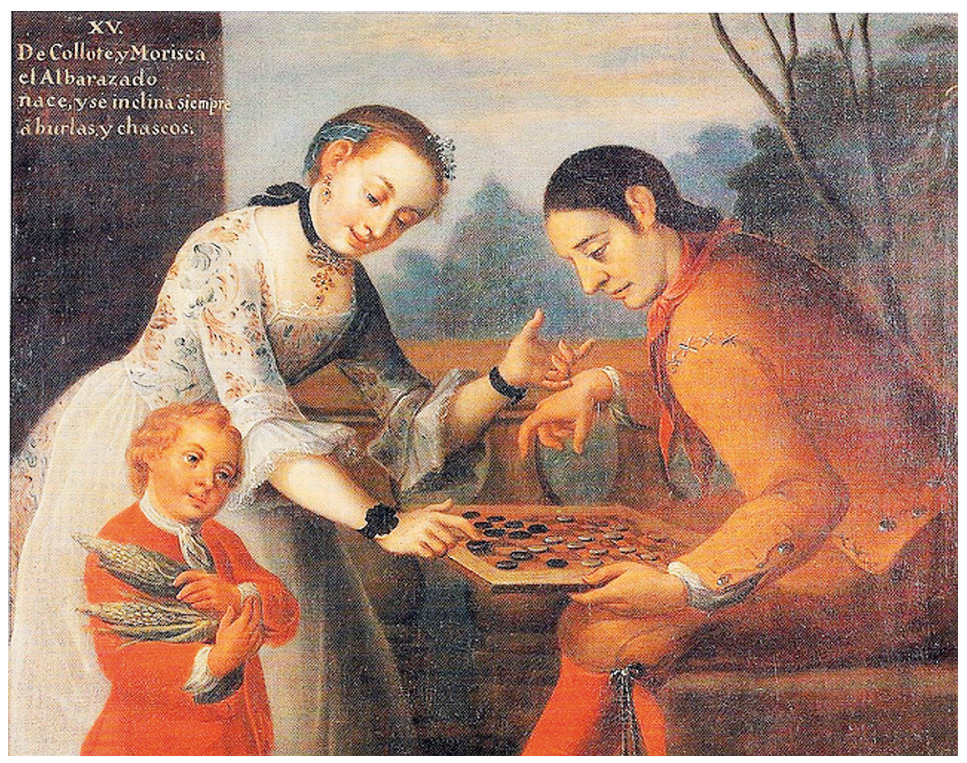

Imagen 6. XV. De Collote y Morisca/ el Albarazado/ nace, y se inclina siempre/ á burlas y chascos. Atribuido a José Joaquín Magón. 


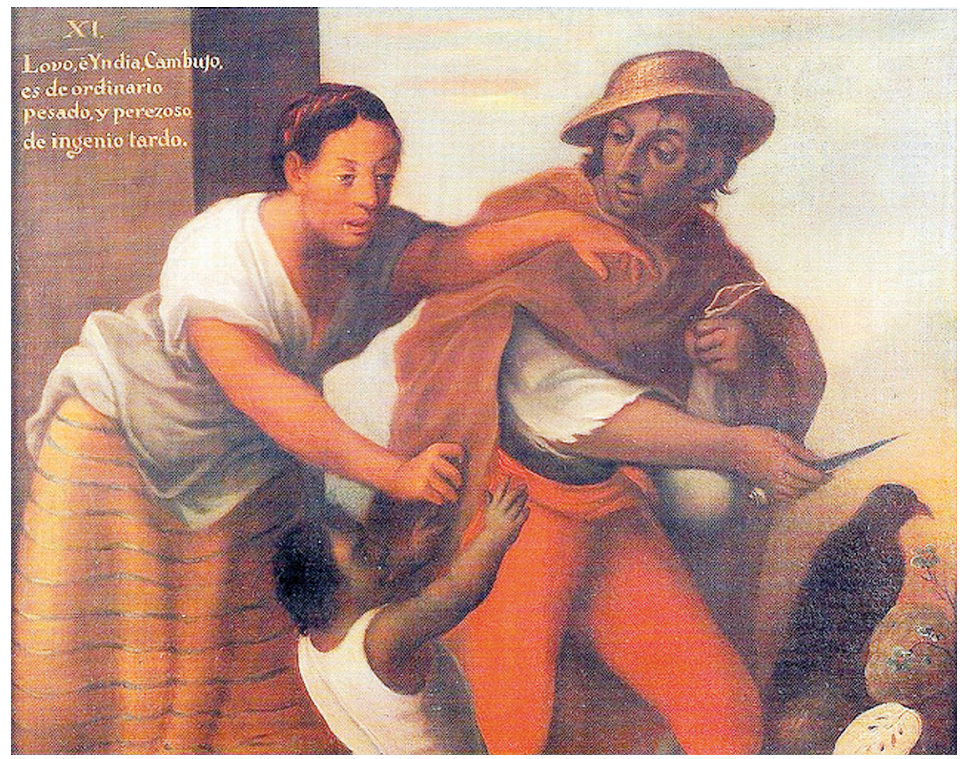

Imagen 7- XI. Lovo e Yndia, Cambujo/ es de Ordinario/ pesado, y perezoso/ de ingenio tardo. Atribuido a José Joaquín Magón.

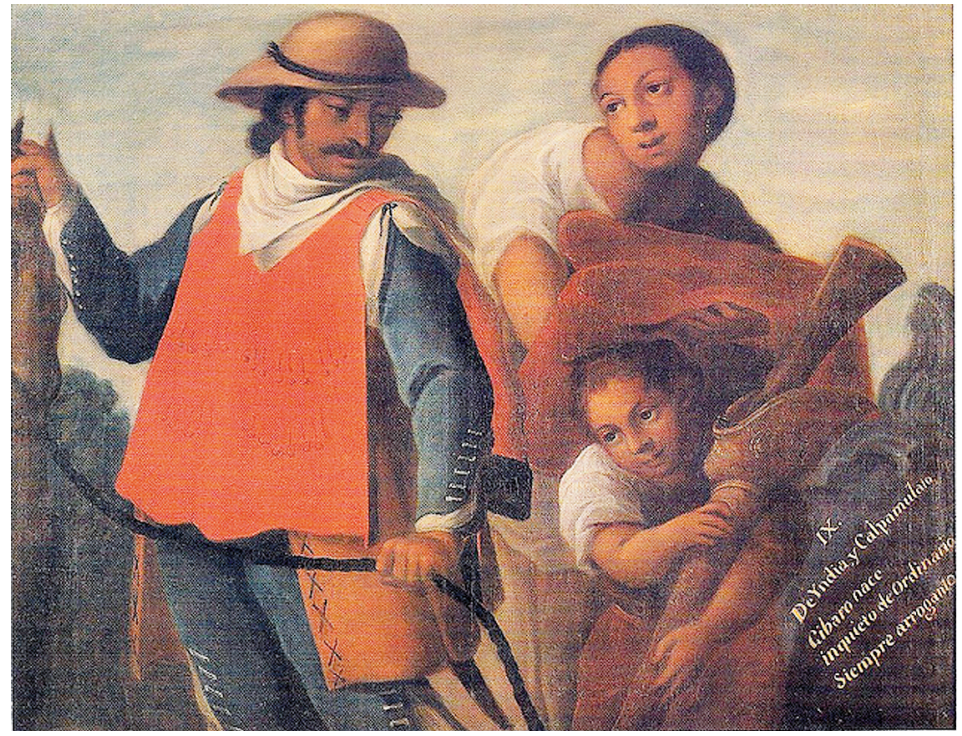

Imagen 8- IX. De Yndia, y Calpamulato/ Gibaro nace/ inquieto de Ordinario/ siempre arrogante. Atribuido a José Joaquín Magón. 


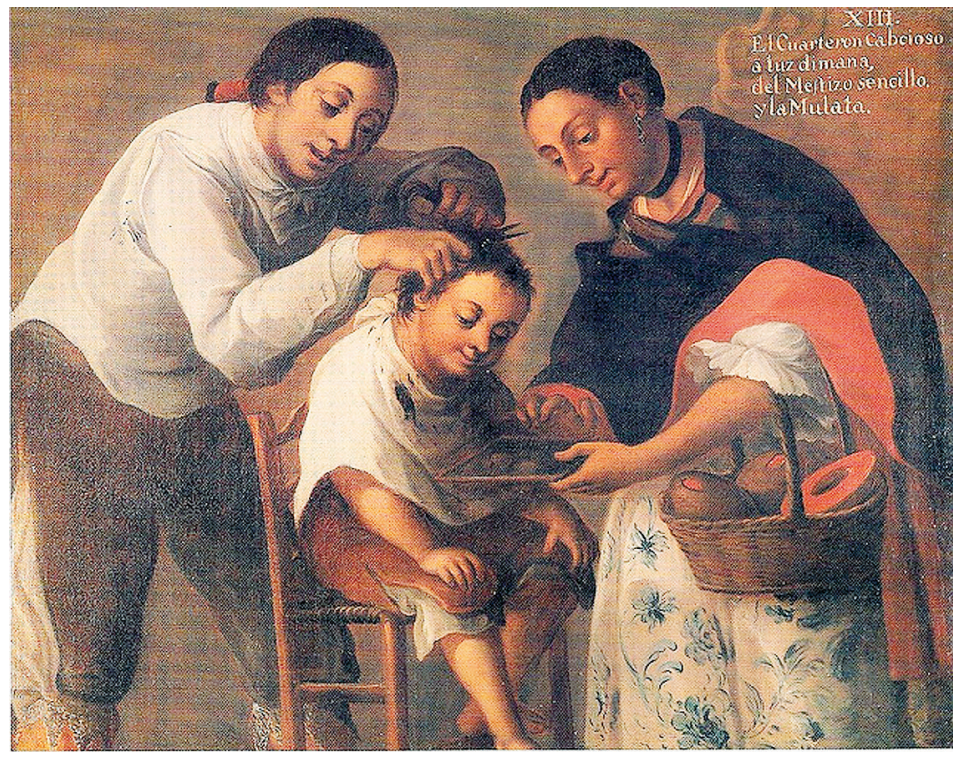

Imagen 9- XIII. El Cuarteron capcioso/ a luz dimana/ del Mestizo sencillo, / y la Mulata.

Atribuido a José Joaquín Magón.

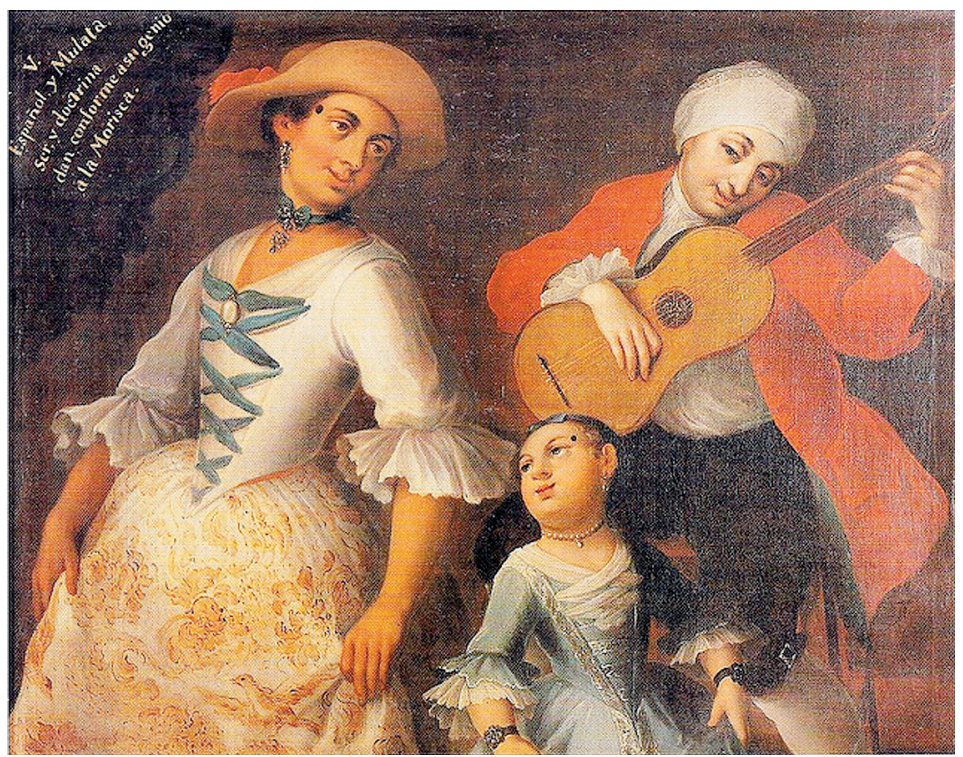

Imagen 10. V. Español, y Mulata/ ser y doctrina/ dan conforme a su genio/ a la Morisca.

Atribuido a José Joaquín Magón. 


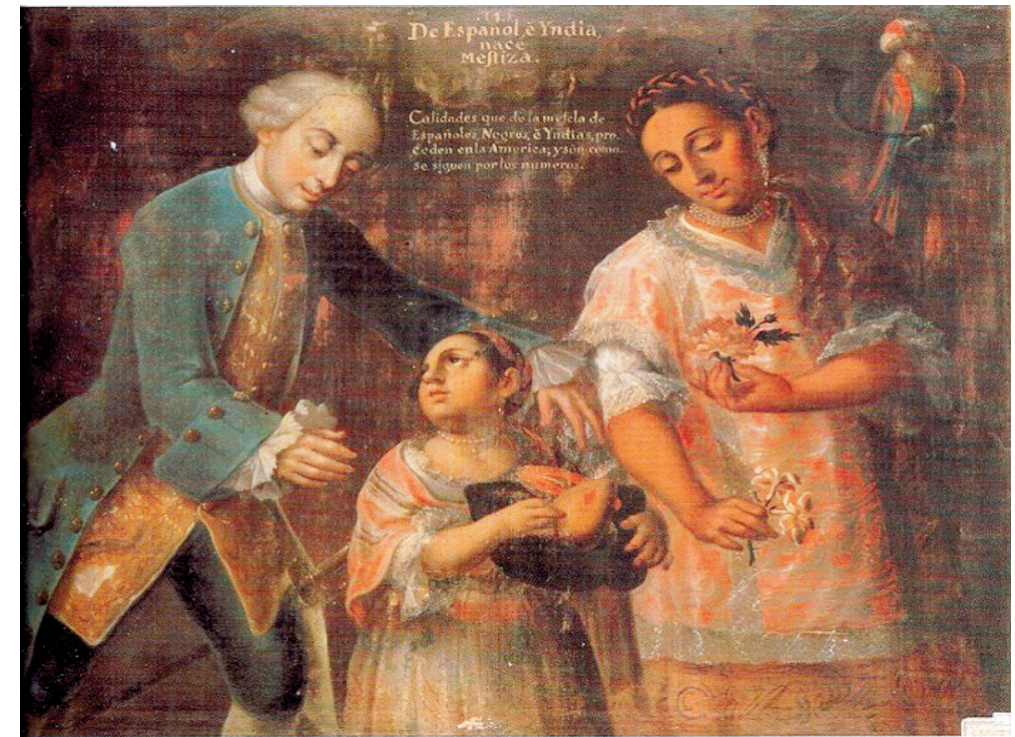

Imagen 11. Primer cuadro de la serie del arzobispo Lorenzana de José joaquin Magón. (1) De Español, é Yndia,/ nace/ Mestiza. 1770.

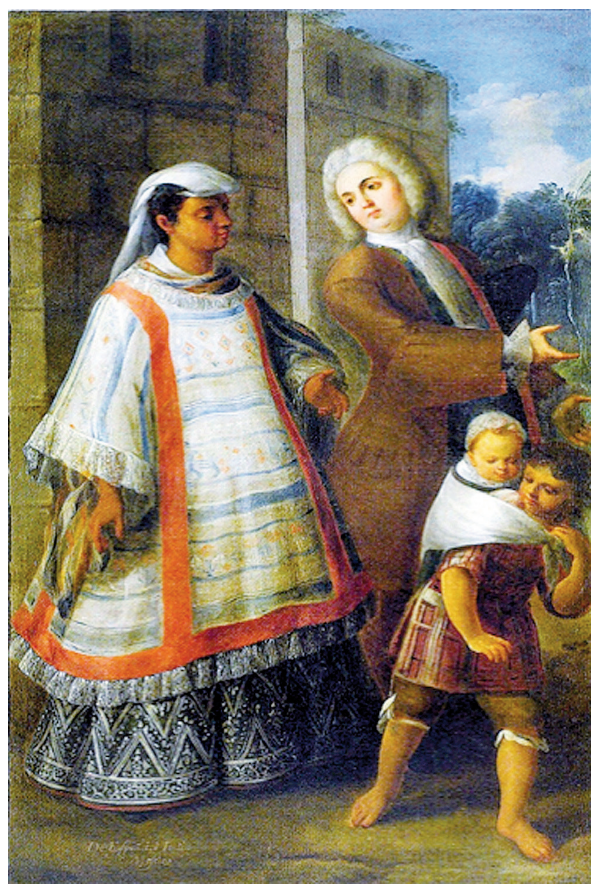

Imagen12. De español e india, mestizo. José de Ibarra. 1725 
Interdiscursividad en la serie de cuadros de castas atribuida al pintor...

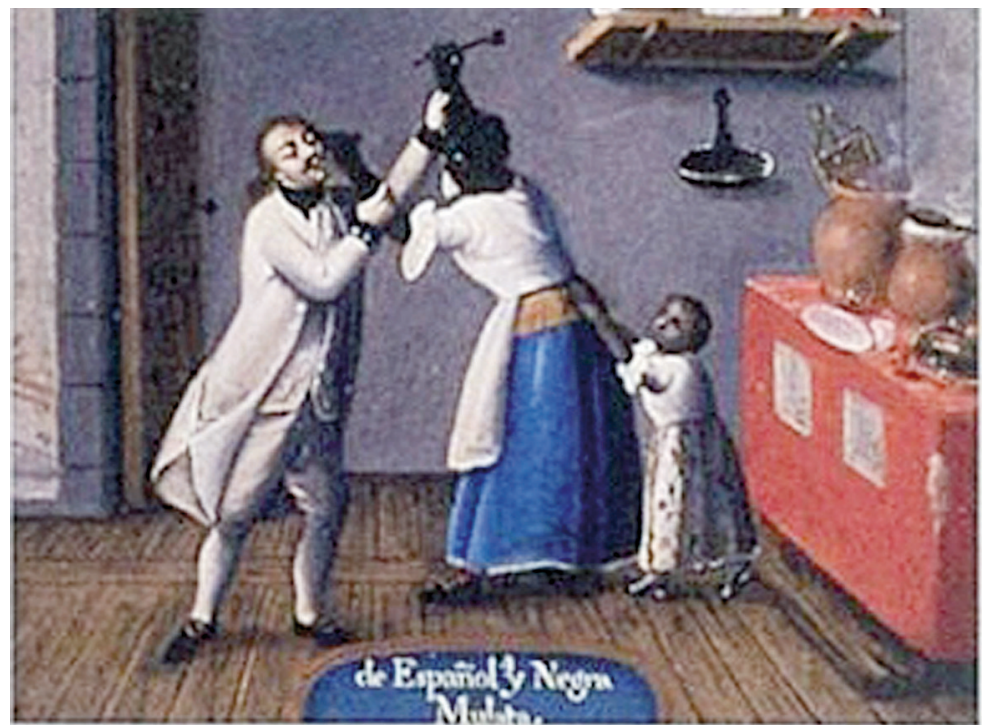

Imagen 13. De español y negra, mulata.

Buenaventura José Guiol. 1770-1780.

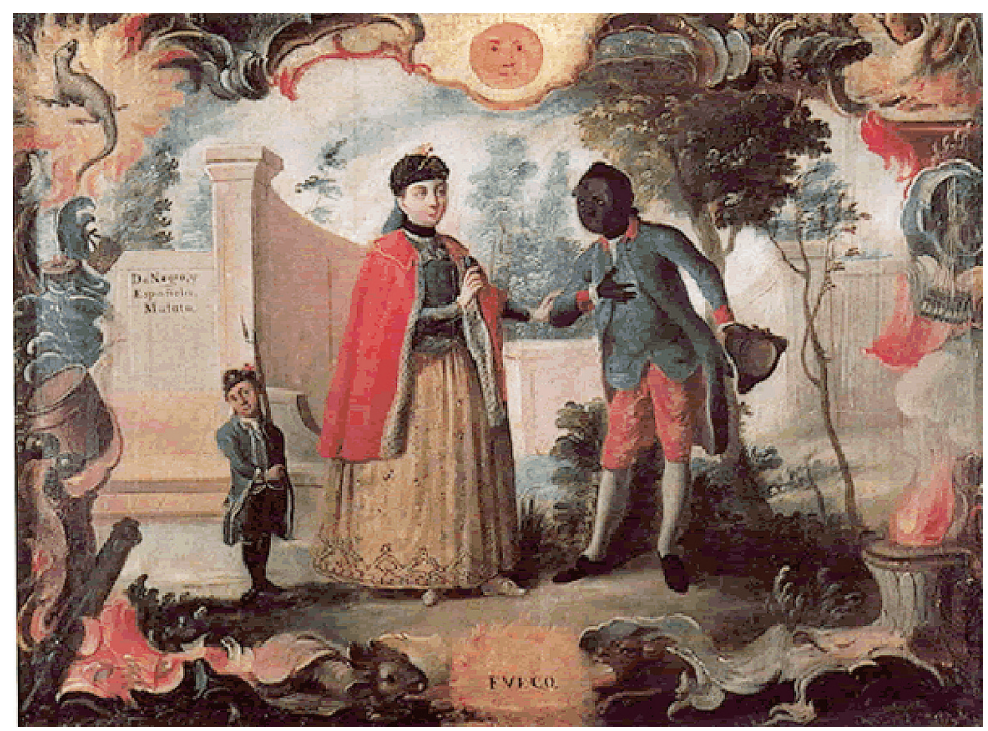

Imagen 14. Serie de castas Anónimo. De negro y española, mulato. 1770. 


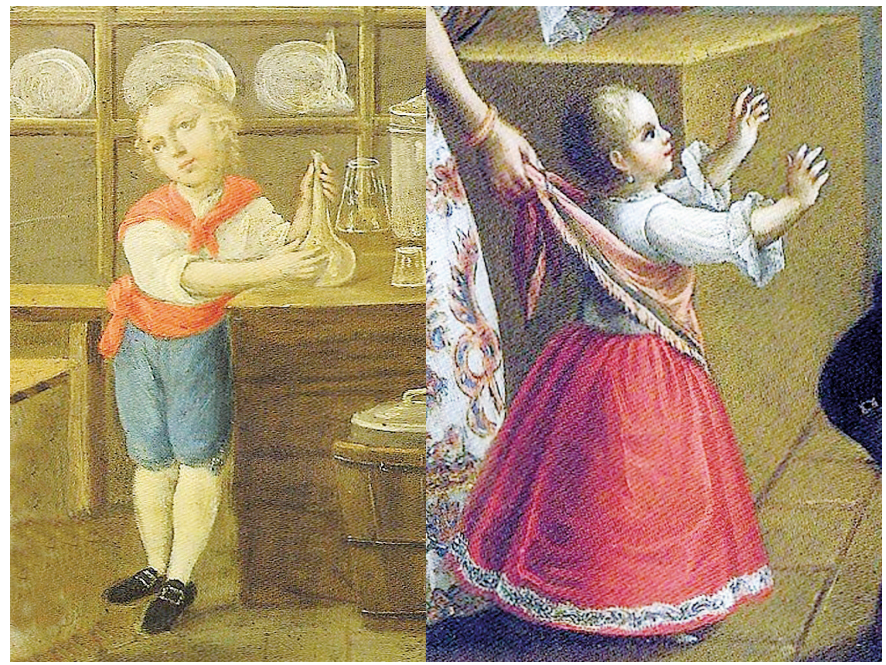

Imagen15. Albino en De español y morisca sale albino de Ramón Torres. 1770-1780 y Albina. En De español y morisca, albina de José de Páez, 1770-1780.

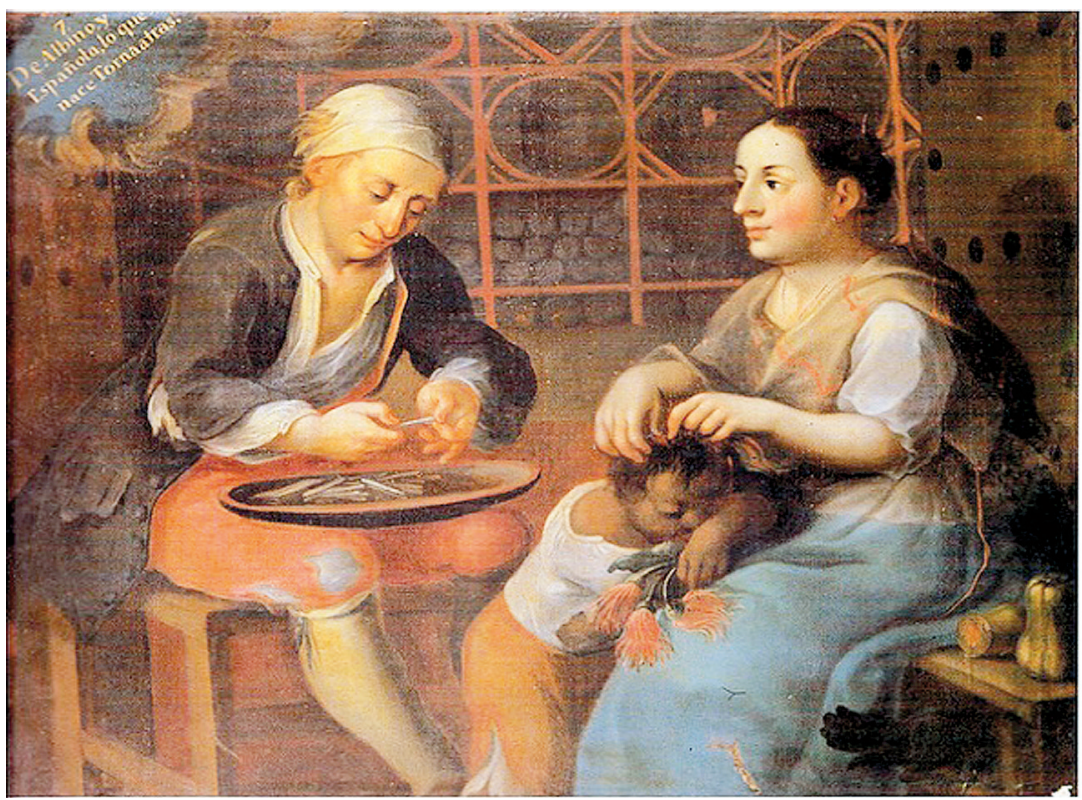

Imagen 16- 7. De Albino, y/ Española, lo que/ nace Torna atras.

José Joaquín Magón, serie del arzobispo Lorenzana. 1770. 


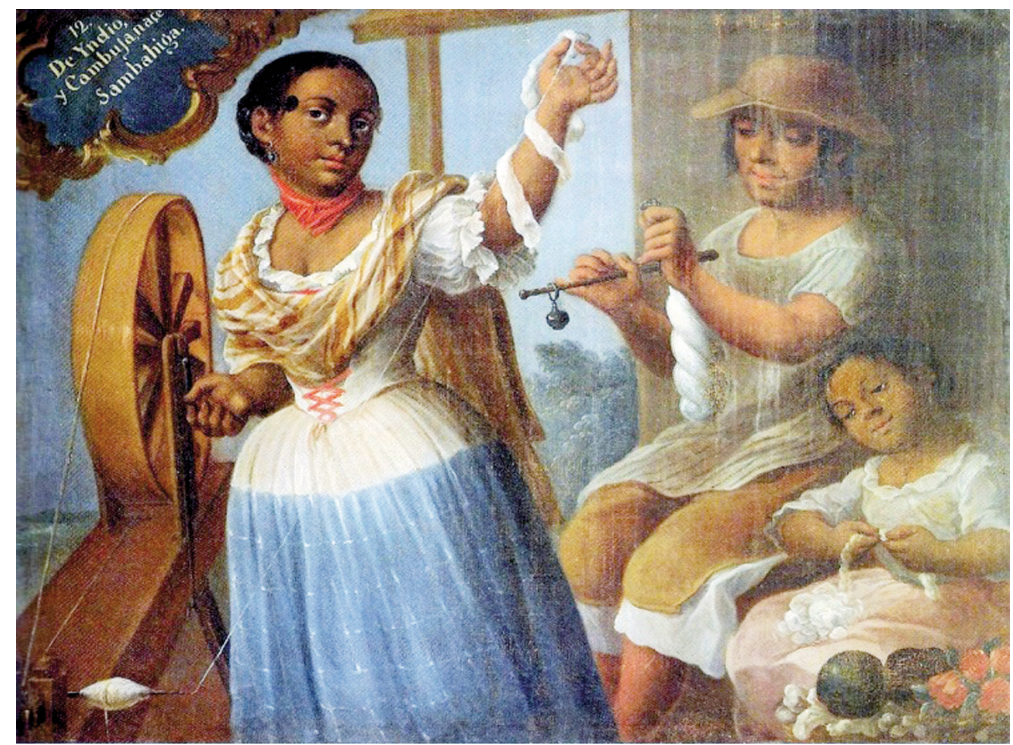

Imagen 17- 12. De Yndio,/ y Cambuja, nace/ Sambahiga. José Joaquín Magón, serie del arzobispo Lorenzana. 1770

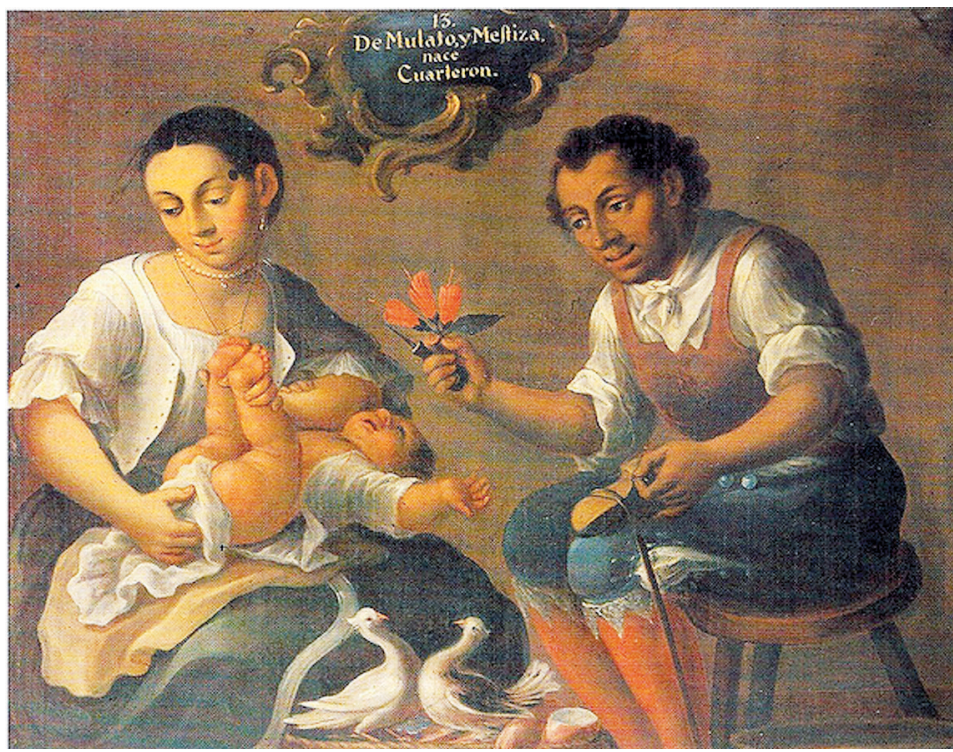

Imagen 18- 13. De Mulato, y Mestiza, / nace/ Cuarteron. José Joaquín Magón, serie del arzobispo Lorenzana. 1770. 


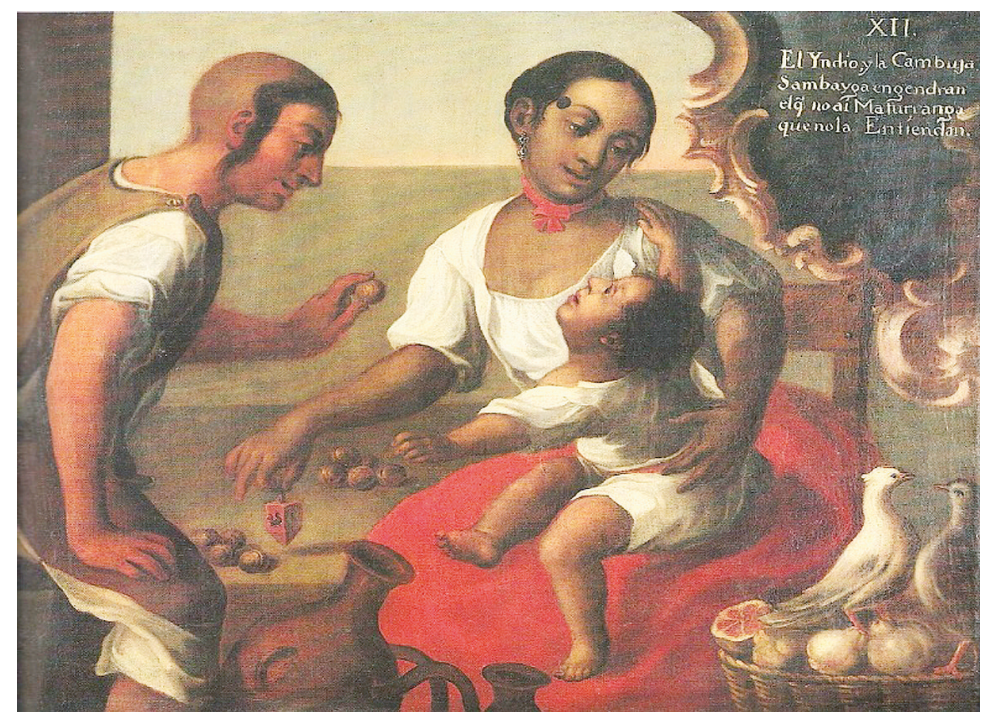

Imagen 19- XII. El Yndio y la Cambuja, /Sambayga engendran/ elq' no ai Maturranga/ que no lo Entiendan. Atribuido a José Joaquín Magón.

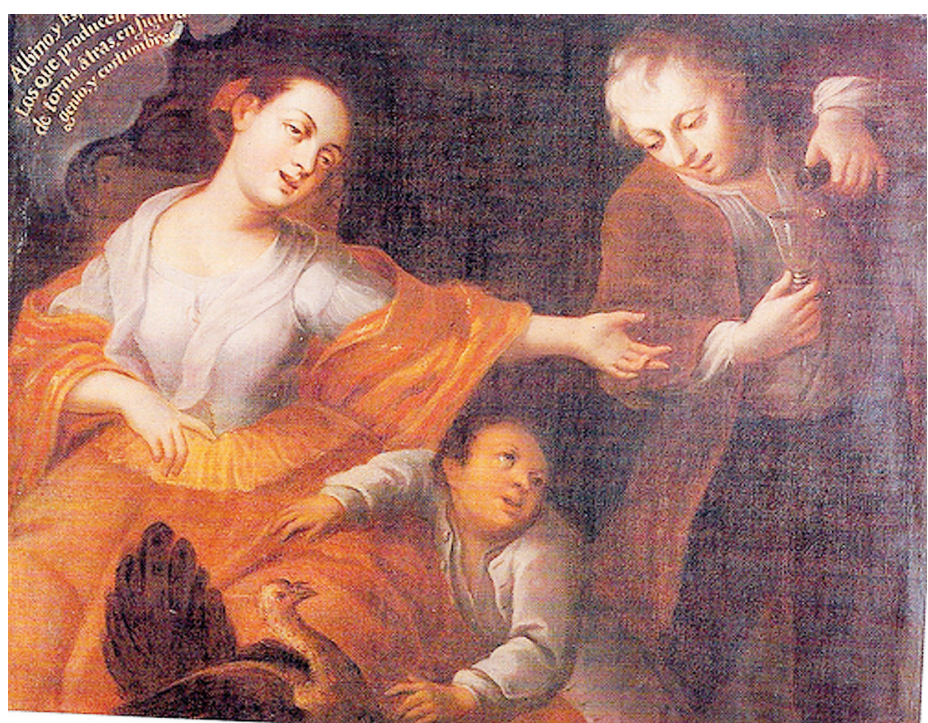

Imagen 20-VII. Albino y Española / los que producen/ de torna atrás en figura/ genio, y costumbres. Atribuido a José Joaquín Magón. 
Interdiscursividad en la serie de cuadros de castas atribuida al pintor...

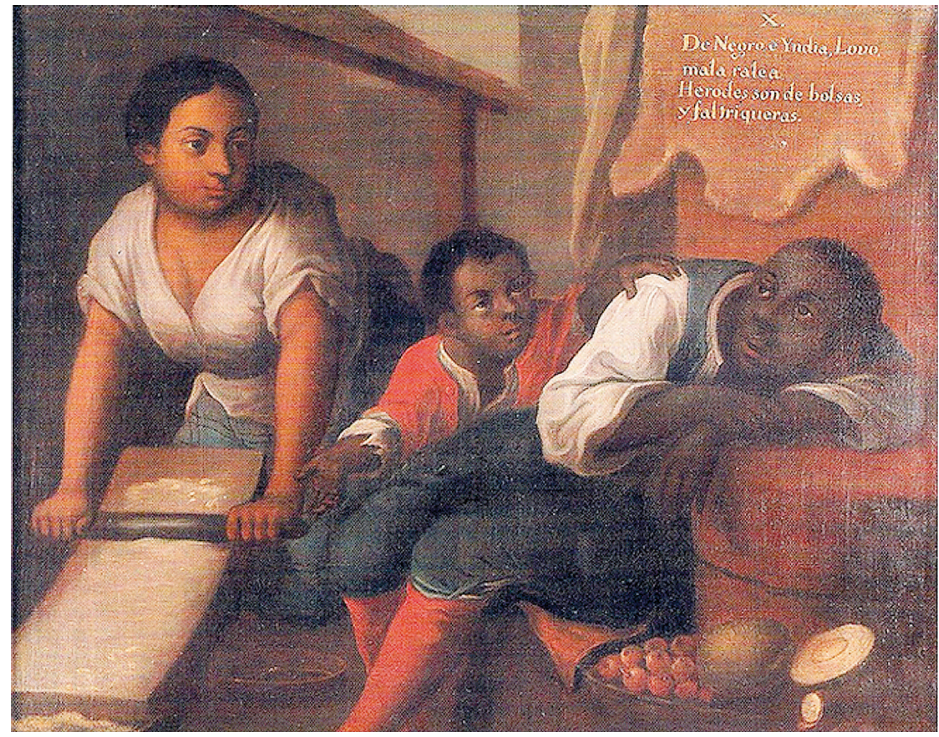

Imagen 21. Detalle del cuadro X. De Negro e Yndia, Lovo/ mala ralea/ Herodes son de bolsas / y faltriqueras.

Atribuido a José Joaquín Magón.

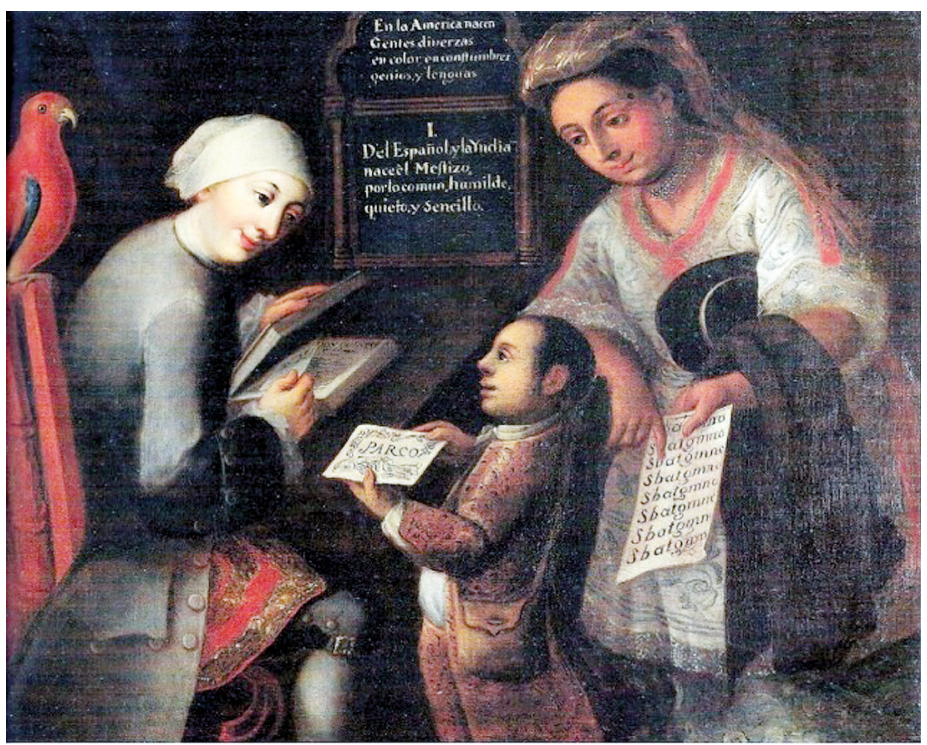

Imagen 22. Del Español y la Yndia/ nace el Mestizo / por lo común humilde/ quieto y sencillo. Atribuido a José Joaquín Magón. 


\section{Bibliografía}

Abad y Queipo, Manuel. "Informe del obispo y cabildo eclesiástico de Valladolid de Michoacán, Abad y Queipo, al Rey, de 1799". En: Humboldt, Alejandro de.Ensayo Político sobre el Reino de la Nueva España. 1799.

Ajofrín, Fray Francisco de. Diario del viaje a la Nueva España. México: Secretaría de Educación Pública, 1986.

Alberro, Solange. Del gachupín al criollo. O de como los españoles de México dejaron de serlo. México: El Colegio de México, 2002.

Arbeteta Mira, Letizia. "Precisiones iconográficas sobre algunas de las pinturas de la colección del Museo de América, basadas en el estudio de la joyería representada”. Anales del Museo de América, No. 15, (2007): 141 - 172.

Calabrese, Omar. Cómo se lee una obra de arte. Madrid: Editorial Cátedra, 1993.

Calatayud Arinero, María Ángeles. "El Real Gabinete de Historia Natural de Madrid". En: M. Sellés, J.L. Peset\& A. Lafuente (comp.) Carlos III y la ciencia de la Ilustración. Madrid, 1987.

Castello, Teresa. "La indumentaria de las castas del mestizaje, en: "La pintura de Castas", Artes de México, No.8, (1998): 72-78.

Castro Morales, Efraín. "Notas”, en Olivares Iriarte, Bernardo. Álbum artístico. Puebla: Secretaría de Cultura del Estado de Puebla, 1987.

De Alba, Martha; Exbalin, Arnaud; Rodriguez, Georgina "El ambulantaje en imágenes: una historia de representaciones de la venta callejera en la Ciudad de México (siglos XVIII-XX)", Cybergeo: European Journal of Geography, (2011), [Online], Dossiers, Ambulantage et 
métropolisation, URL: http://cybergeo.revues.org/5591;

DOI: $10.4000 /$ cybergeo.5591.

Ebert, Anne. "La representación de las américas coloniales en los cuadros de castas". Revista Scientia Vol. X: No. 10, pp. 139-152.

Florescano, Enrique. Etnia, estado y nación. Ensayo sobre las identidades colectivas en México. México: Taurus, 2008.

García Saiz, María Concepción. Las castas mexicanas. Un género pictórico Americano. Milán: Olivetti, 1989.

Gerbi, Antonello. La disputa del Nuevo Mundo. Historia de una polémica 1750 1900. México: Fondo de Cultura Económica, 1960.

Gruzinski, Serge. La guerra de las imágenes. De Cristobal Colón a "BladeRunner". (1492-2019). $1^{\text {a }}$ reimpresión. México: Fondo de Cultura Económica, 1995.

Gumilla, Joseph. S. J. El Orinoco Ilustrado y Defendido. Caracas: Academia Nacional de La Historia, 1963.

Hering Torres, Max S. "Color, pureza, raza: la calidad de los sujetos coloniales". En: Bonilla, Heraclio (Ed.): La cuestión colonial. Bogotá: Universidad Nacional de Colombia, 2011.

Humboldt, Alejandro de. Ensayo Político sobre el Reino de la Nueva España. México: Porrúa, 1984.

Katzew, Illona. La pintura de castas. Representaciones raciales en México del siglo XVIII. Madrid/México D.F.:2004. Turner, que no cita la serie atribuida a Magón.

León, Nicolás. Las castas de México Colonial o Nueva España. México: Talleres Gráficos del Museo Nacional de Arqueología, 1924, pp. 9-10. 
Lafaye, Jacques. Quetzalcóalt y Guadalupe. La formación de la conciencia nacional en México. México: Fondo de Cultura Económica, 1974.

Lozano Armendares, Teresa. "Los Juegos de Azar, ¿Una Pasión Novohispana?.

Legislación sobre juegos prohibidos en Nueva España, siglo XVIII”. Estudios de Historia Novohispana, Vol. 11:No. 011 (1991):155-181.

Lucena Giraldo, Manuel. Naciones de Rebeldes. Las revoluciones de independencia latinoamericanas. Madrid: Taurus Historia, 2010.

Masera, Mariana; Krutitskaya, Anastasia; Camastra, Caterina. "Con esta no diré más: sones y coplas de la Nueva España". Revista de Literaturas Populares, Año X: Nos. 1 y 2, (enero-diciembre, 2010): 103-135.

Moreno Navarro, Isidoro. "Un aspecto del mestizaje americano: El problema de la terminología". Revista Española de Antropología Americana, No. 4 (1969): 201-218.

Real Academia Española (RAE). Diccionario de la Lengua Española, decimonovena edición. Madrid, 1983.

Rodríguez Jiménez, Pablo. "Sangre y mestizaje en la América Hispánica”. Anuario Colombiano de Historia Social y de la Cultura, No. 35 (2008): 279-310.

Ronda Bucio, Evelina. "Vestimenta como elemento que identifica un estrato social en Valladolid, segunda mitad del siglo XVIII". (Tesina para obtener el título de Licenciado en Historia. Universidad de Michoacán, Morelia, México, 2011).

Stolke, Verena. "Los mestizos no nacen sino que se hacen". En: Stolcke, Verena y Coello, Alexandre (editores), Identidades Ambivalentes en América Latina (Siglos XVI-XXI). Barcelona: Bellaterra, 2007. 
Interdiscursividad en la serie de cuadros de castas atribuida al pintor...

. "Los mestizos no nacen sino que se hacen". Avá, Posadas, No. 14, (julio- 2009). Disponible en http://www.scielo.org.ar/scielo.php?script=sci_arttext \&pid=S1851-16942009000100002\&lng=es\&nrm=iso>. (Acceso 15 de marzo, 2012).

Todorov, Tzvetan. Nosotros y los otros. Reflexión sobre la diversidad humana. Quinta reimpresión. México: Siglo XXI Editores, 2009.

Tovar y de Teresa, Guillermo. Repertorio de artistas en México, T. II. México: Bancomer, 1996.

Ulloa, Antonio y Juan, Jorge. Relación histórica de un viaje a la América Meridional Tomo I, Cap. IV. Madrid: Dastin, 2002.

Viera, Juan de. "Breve compendiosa narración de la ciudad de México, en el siglo XVIII". En: La Ciudad de México en el siglo XVIII (1690-1780): Tres crónicas. Augustín de Vetancurt, Juan Manuel de San Vicente, Juan de Viera. Edición de Antonio Rubial. México: Conaculta, 1990.

\section{Citar este artículo:}

Luis Augusto Mora y Abel Fernando Martínez, "Interdiscursividad en la serie de cuadros de castas atribuida al pintor novohispano José Joaquín Magón”, Revista Historia y Memoria, No. 08 (enero-junio, 2014), pp. 245-295. 